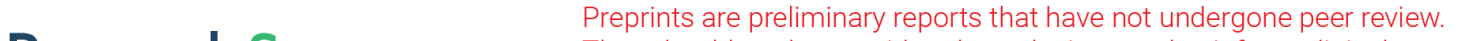 They should not be considered conclusive, used to inform clinical practice, or referenced by the media as validated information. \\ Spatial Modeling of River Bank Shifting and Associated LULC Changes of the Kaljani River in Himalayan Foothills
}

\section{Md. Hasanuzzaman}

Raja N.L.Khan Womens College

\section{Amiya Gayen}

University of Calcutta

\section{Sk. Mafizul Haque}

University of Calcutta

Pravat Kumar Shit ( $\triangle$ pravatgeo2007@gmail.com )

Raja N.L.Khan Womens College https://orcid.org/0000-0001-5834-0495

\section{Research Article}

Keywords: erosion, accretion, DSAS model, CA-Markov model, channel shifting, SCS-CN

Posted Date: June 1st, 2021

DOI: https://doi.org/10.21203/rs.3.rs-336521/v1

License: (9) This work is licensed under a Creative Commons Attribution 4.0 International License. Read Full License

Version of Record: A version of this preprint was published at Stochastic Environmental Research and Risk Assessment on January 12th, 2022. See the published version at https://doi.org/10.1007/s00477021-02147-1. 
3

4 Md. Hasanuzzaman ${ }^{1}$; Amiya Gayen ${ }^{2}$ Sk. Mafizul Haque ${ }^{2}$ and Pravat Kumar Shit ${ }^{1 *}$ 5$$
7
$$

8

12

13

14

15

16

17

18

19

20

21

22 Pravat Kumar Shit

23 Email: pravatgeo2007@gmail.com

24

25

26

27

28 Kaljani River in Himalayan foothills

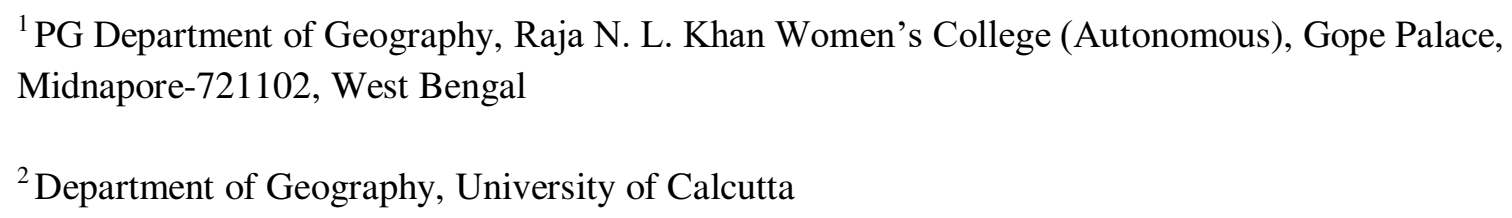

Md. Hasanuzzaman

Email: $\underline{\text { hasan20geo@gmail.com }}$

4

Amiya Gayen

Email: mr.amiyagayen@gmail.com

7

Sk. Mafizul Haque

Email: mafi haque@yahoo.co.in

0

1

*Corresponding author: email: pravatgeo2007@gmail.com (Pravat Kumar Shit)

6

7

8

\section{Spatial modeling of river bank shifting and associated LULC changes of the}




\section{Spatial modeling of river bank shifting and associated LULC changes of the Kaljani River in Himalayan foothills}

\section{Abstract}

Channel dynamics is an inherent characteristic of the river in the floodplain region. The river bankline shifting and associate land use land cover (LULC) change is not only geomorphological but also an environmentally vital hazardous issue. It is a significant impact on the ecosystem and human life. GISbased, DSAS and CA-Markov models are efficient to accurately measure historical and predictionevaluation of the relation between channel shifting and LULC change. In this study, forty-eight years (1972-2020) of earth observatory data have been used to demarcate the channel bank position and LULC change detection along the Kaljani River at the eastern Himalayan foothill. During 1998-2008, very high erosion rate on both bankline, which are about $-4.48 \mathrm{~m} / \mathrm{y}$ and $-3.48 \mathrm{~m} / \mathrm{y}$ at the left and right, respectively compared the others time frame. The overall result of the predicted bankline represents that the bulky expansion will occur along the left bank and sediment accretion will take place at the right bank. Among the three zones, both banks of zone 'A' (lower part of the river) is the worst affected part in the past, present, and future time. The LULC change of all six classes from 1972 to 1998 was very high when compared with the change between 1998 and 2020. Moreover, the long profile, hypsometric curve value, and the Soil Conservation Service Curve Number (SCS-CN) value have been a significant help in understanding and identification of consequences reasons. The level of accuracy is validated by the observed bankline positions (2020) with predicted bankline (2020) and observed LULC (2020) to predicted LULC (2020) empirically with RMSE and statistical test. Therefore, the output of the prediction not only serves as the spatial guidelines for monitoring future trends of channel shifting and land use planning management.

Keywords: erosion, accretion, DSAS model, CA-Markov model, channel shifting, SCS-CN.

(1)

\section{Introduction}

Systematic assessments onriver bank erosion-accretion and its positionare very complex and difficult tasks in the field of geomorphology (Lawler 1993). The morphological position changes of the river channel, especially its lateral migration, erosion-accretion and bank instability aremost important research themes in geomorphology as well as engineering platforms now a days (Langat et al., 2019; Suhaimi et al., 2018; Langat et al., 2019). A large part of the fluvial studies has been a focus on the dynamicity of river system overtime (Petts, 1995). Butpositional changes of channel geometry along with its discharge flow, erosion-accretion and channel migration of the river (Abbe and Montgomery, 2003; Kleinhans, 
2010; Gurnell et al., 2012) were overlooked due to the paucity of data integration systematically. Similarly, the hydrodynamic behavior of channel flow and sedimentation nature are resultant imprints of the riverbank erosion-accretion process (Ashraf \& Shakir, 2018; Yu et al., 2018; Moradi et al., 2018; Langat et al., 2019). The effect of extreme bank erosion contributes almost 90 percent of sediment loads in the tropical rivers (Steel \& Milliken, 2013). Although, bank erosion-accretion depends on various factors such as ground slope, river discharge, drainage basin area, geo-tectonically built activities, flooding, bank structure, topography, soil properties, the density of vegetation and climatic exigencies etc. but discharge fluctuation is considered as most significant controlling factor (Hooke, 1979). On the other hand, natural and anthropogenic activities are one of the main causes which govern the amount and the rate of river erosion-accretion mechanism (Suizu\& Nanson, 2018). Alluvial river basin area on the foothill trackis characterizedby bank erosion and it occurs numerous problems (Ercan and Younis 2009). Similarly, river bank raises different significant economic and environmental problems such as loss of infrastructure and agricultural land due to rampant bank erosion (Ashraf \& Shakir, 2018) which creates great threat to local people. The vast dimension of floodplain areas is one of the most attractive land resources for human society but worldwide these plains are facing land degradation by riverbank erosion and huge land use alteration (Hazarika et al., 2015; Debnath et al., 2017).The channel erosion-accretion process changes LULC of the bank adjacentvillage areawhich causes disastrous exposure to the local people (Thakur et al., 2012). Thus, dynamicity of the channel with changing LULC practicesnow becomes one of the challengestothe decision-makers and engineers for their policy-making, floods controls, embankment constriction purposes (Debnath et al., 2017). The delineation of vulnerable zones is a critical task for planning and management of land resources, and its efficient mapping can able to develop of early warning systems (Eastaugh and Hasenauer, 2014).

For the geomorphic assessment of bank's features like measuring, mapping, representing and monitoring; capable and effective tools and techniques are very important. At present, earth observatory techniques like remote sensing (RS) and geographic information systems (GIS) have performed an enormous role for change detection and mapping in river systems including buffer zone dynamics at a different strategic scale (Wang and Mei, 2016; Wang and Xu, 2018). RS and GIS platform with field verification can accurately and quickly map and investigate the river morphological changes (Rinaldi et al., 2013, Langat et al., 2018). The riverbank erosion-accretion and LULC change on behalf of channel morpho-position changes; this present study tries to relate both changes using the modern geospatial tools and techniques (Debnath et al., 2017; Lawler, 1993,Jana, 2019) and LULC changes (Ahmed, 2012; Mondal et al., 2016; Maviza and Ahmed, 2020), their future prediction (Miall et al., 2018; Mansour et al., 2019; Nurwanda and Honjo, 2019) based on the hydro-geo-morphic data on the multi-temporal scale (long, intermediate, and short-term). In GIS based spatial analysis attributes both linear (here river bank) and aerial (here 
floodplain area) segments of the study area have been considered for assessing the temporal trends. Therefore, the digital shoreline analysis system (DSAS) is a highly acceptable method, developed by the United States Geological Survey (USGS), capable to accurately measure the rate and predication of different river bank line positions (Right and left bank separately) (Thieler et al. 2009; Kankara et al. 2015; Ashraf andShakir, 2018; Jana, 2019). Generally, the DSAS model has been used in the context of the sea shoreline. However, in the study of the river, the right and the left bank can be separately mapped with a higher degree of accuracy. The CA-Markov model has an ability to the prediction of LULC changes and it can delineate the LULC change pattern (Xiao et al. 2012; Hamad et al. 2018; Mansour et al. 2019; Nath et al. 2020; Wang et al. 2020; Du et al. 2020).

The study area is situated on the scismo-tectonically unstable foothill terrain of Bhutan Himalaya, has produced array of magnificent landscapes both physical \& cultural involving multiple cycles of fluvial erosions (Chakrabarti Goswami et al., 2013). This work has been developed for the determination of the historical bank line, calculation erosion-deposition, and LULC change by the graphical and mathematical methods with the field verification. The efforts to measure erosion-accretion and LULC change of Kaljani River adjacent village area is completely absent, it makes this study as exceptional. According to annual flood report the Kaljani River area is geomorphologically active for its erosion-accretion nature (West Bengal annual flood report, 2013; 2014; 2016). Therefore, this work is not only an attempt to measure the erosion-accretion and LULC change over four decades but it predicts future trends for the year 2025, 2035, and 2045. Thus, channel and LULC change management is necessary for the sustainable use of land resources, protection of people's property, and lives (Thakur et al. 2012 and Debnath et al. 2017).

\section{Study area}

The Kaljani River is a tributary of Torsha River, originated in Bhutan at the foothills of the Himalayas and it flows from north to south via Bhutan and India and confluences with Torsha River that again joins in the mighty Brahmaputra River and eventually merges with Padma River to reach the Bay of Bengal. The Kaljani River has negotiated the undulating Bhutan Himalaya terrain with the alluvial fans and the Terai plain downstream thus covers both the 'Bhabar' and the continuous plains of 'Terai' downhill. The major tributaries of Kaljani River are Dima, Nonai, etc.

The Kaljani River is situated in the Eastern and North-Eastern part of Alipurduar and Cooch Behar district in West Bengal. The region extends from $26^{\circ} 43^{\prime} 08^{\prime \prime} \mathrm{N}$ to $26^{\circ} 16^{\prime} 30^{\prime \prime} \mathrm{N}$ latitude and $89^{\circ} 25^{\prime} 17^{\prime \prime} \mathrm{E}$ to $89^{\circ} 34^{\prime} 56^{\prime \prime}$ E longitude. The length of the river within the study area is $80.5 \mathrm{~km}$. The authors have identified 45 mouzas (smallest administrative unit for revenue collection)along the Kaljani River buffer zone(adjacent village areas) for this research work. These adjacent village areas have maximum stretch of $5.88 \mathrm{~km}$ and minimum of $1.64 \mathrm{~km}$ from the channel thalweg. For the simplification of the study the 
adjacent village area is divided into three zones, namely (A) Deocharai to Ambari stretch, (B) Ambari to Dakshin Paitkaparastretch, and (C) Dakshin Paitkapara to GabaurBachhra forest stretch spacing around 26.8 km (Fig. 1).

Fig. 1: Location map of the study area (A) India, (B) Eastern Himalayan foothill, (C) Kaljani River Basin with altitude, and (D) Kaljani River Buffer Mouza.

\section{Methodology and database}

3.1 Database preparation: In this study MSS, TM,ETM+, and OLI datasets collected for 1972, 1987, 1998, 2008, and 2020 were used to demarcate the channel banklines and LULC change detection (Table 1). The recent image of 2020 was also used to validate 2020 predicted result. All the satellite images were projected in the Universal Transverse Mercator (UTM) projection with zone 45 north and world geodetic survey 1984 (WGS84) datum and resampled in the ArcGIS environment. To maintain the data quality, all the images have been co-registered using the first-order polynomial model with the accuracy of root mean square error (RMSE) of less than 0.5 pixels with a minimum number (here it is 5) of ground control points (GCPs). Based on the axial length of river stretch and meander nature, the entire selected course of Kaljani River was segmented into three distinct zones (A, B, and C) with extension of $26.8 \mathrm{~km}$ (Fig. 1) for the in-depth explanation of the model result. Afterward, around 378 transects (on both banks) are generated in each of these zones for the estimation of riverbank shifting/ erosion-accretion rate.Coppernnicus aerial imagery has also been used for river bank embankment length measurement andprimarydata verification. The work has been carried out as per the following methodology (Fig. 2).

Table 1: Characteristics of selected satellite images.

Fig. 2. Conceptual framework of the methods used.

3.2 Bank lines extraction:This process has been adopted for the assessment of earlier bankline position with the help of selected satellite images. The bankline extraction is the process of transformation of the image, into a vector layer from raster data-structure to determine right and left banklines separately on particular imagery (Jana, 2019). Authors have used the normalized difference water index (NDWI) after McFeeters, 1996; Haque et al. 2020 and modified normalized difference water index (MNDWI) (Xu, 2006) for bank line extraction based on Eq. 1 and 2 which employed green and NIR bands for segregation of land from water. Where, pixels for water features are assigned as ' 1 ' and for land as ' 0 ' to achieve a binary image. 
To estimate the MNDWI, the MIR band of Landsat 7 and SWIR band of Landsat 5 and 8 along the green band are also used. The technique for calculating the MNDWI was given by $\mathrm{Xu}(2006)$ as:

$$
\text { MNDWI }=\text { Green }- \text { MIR } / \text { Green }+ \text { MIR }
$$

MNDWI = Green - SWIR/Green - SWIR

(Eq. 3)

The outputof these two ratios (NDWI and MNDWI) were further multiplied to generate another new image where isolated pixel of product image nullified through the filtering technique of local mean matching (de Bethune et al., 1998) for detection of bank line position.

3.3 Estimation of erosion-deposition rate and its prediction:In the present work, the Digital Shoreline Analysis System (DSAS) extension tool of ArcGIS was used to assess the rate ofbankline erosionaccretion and subsequently, its predictionalso estimated by using the reference extracted baselines and auto-generated transects. For the DSAS based statistical output, two further models have been employed like, End Point Rate (EPR) model for computing presentbanklineerosion-accretion or shifting rate and Linear Regression (LRR) model for future banklineestimation.

3.3.1 EPR model for calculating the bankline erosion-accretion rate/shifting rate: In the EPR model, based on availability of data the considering time period is divided into four temporal datasets i.e., 1972 to 1987,1987 to 1998,1998 to 2008, and 2008 to 2020 (Fig. 3). For each dataset, superimposed bankline positions have been portrayed and achieved a final line of overlapping visualization and this line is traced out as a composite line. Afterward, a buffer of $100 \mathrm{~m}$ distance from the composite line is drawn towards the right for the right bank and left for the left bank to demarcate the baselines. Therefore, a number of transects have been placed at 50-metergap on the baseline are created at the acute angleto the baseline up to $3.5 \mathrm{~km}$ distance away from both banks, and transects are auto-generated with $\pm 0.5 \mathrm{~m}$ uncertainties depending on the orientation of the baselines. Moreover, around 1135 transects are placed along the baseline with $50 \mathrm{~m}$ spacing to cover the entire selected tract ofKaljani River (about $80.5 \mathrm{~km}$ ) (Fig. 3).

\section{$E P R=\frac{\text { Distance of bankline movement }}{\text { Time between oldest and most recent }}($ Eq. 4$)$}

In EPR model, previous and recent data of two banklines are needed for this calculation and do not require any earlier knowledge regarding the hydraulic interference or sediment transport. Moreover, this model is applied for two years of a data set viz. 1972 to 1987, 1987 to 1998, 1998 to 2008, and 2008 to 2020 forcalculating the riverbank erosion-accretion rate which depicts the shifting trend over time.

The result of EPR is applied to calculate the rate of bankline migration and understand the erosionaccretion nature (Mukhopadhyay et al. 2012; Jana, 2019) using the ' $Y$ ' for positions of earlier ( $\left.Y_{o b}\right)$ and recent ( $Y_{r b}$ )bankline. In this attempt, it is used as ' $Y$ ' to denote the projected bankline position which is estimated by following Eq. 
On the other hand, EPR intercept is calculated by Eq. 6 .

$$
\alpha_{E P R}=Y_{o b}-\left\{\frac{Y_{o b}-Y_{r b}}{X_{r b}-X_{o b}}\right\} X_{o b}=Y_{r b}-\left\{\frac{Y_{o b}-Y_{r b}}{X_{r b}-X_{o b}}\right\} X_{r b}
$$

The rate of bankline migration for a given set of transects, the $\beta_{E P R}$ is calculated by the Eq.7

$$
\beta_{E P R}=\left\{\frac{Y_{o b}-Y_{r b}}{X_{r b}-X_{o b}}\right\}
$$

Fig. 3 Different banklines $(1972-2020)$ are positioned along the baseline. All transects are oriented at angle with the corresponding baselines.

3.3.2 LRR model for predicting the bankline erosion-accretion/shifting rate:LRR model usesstatistics of model generated baseline, which is demarcated by temporal period of bankline migration for 1972-1987, 1987-1998, 1998-2008, and 2008-2020shows bank position of the subsequent year of the selected timespan. Therefore, the channel side position of the data set 2020 is considered as a common baseline to all sets. The result of this attempt has been scrutinisedby the least-square method (fitting a regression line) to predict the channel shifting and bankline position (Thieler et al., 2009). For this a regression line is placed to all linear series, points along a user particulartransect. Afterward the riverbank shifting rate is estimated by fitting the least-square regression lines to all bankline points for a defined transect. Therefore, this model is used for predicting the position of banklineat short-term (2025), intermediateterm (2035) and long-term (2045) basis with a period of 7 years, 17 years and 27 years, respectively in respect to the position of banklinein 2020. Also 2020 bankline position predicted for accuracy assessment. Then the value of EPR is used to predict the future of riverbank positions $\left(Y_{p b}\right)$. This is because the predicted riverbank position $\left(X_{p b}\right)$ can extend beyond the recent riverbank (either at left or right).Hence, the Eq. 5 is modified and formulated through LRR by the following Eq. 8.

$$
Y_{p b}=\left\{\beta_{E P R}\left(X_{o b}-X_{r b}\right)\right\}+Y_{r b}
$$




$$
R M S E=\left[n^{-1} \sum_{i=0}^{n}\left(X_{m b}-X_{\mathrm{ab}}\right)^{2}+\left(Y_{m b}-Y_{\mathrm{ab}}\right)^{2}\right]^{1 / 2}
$$

221

222

223

224

225

226

227

228

229

230

231

232

233

234

235

236

237

238

239

240

241

242

243

244

$245 \quad P=\left(P_{i j}\right)=\left|\begin{array}{cccc}P_{11} & P_{12} & \Lambda & P_{1 n} \\ P_{21} & P_{22} & \Lambda & P_{2 n} \\ \Lambda & \Lambda & \Lambda & \Lambda \\ P_{n 1} & P_{n 2} & \Lambda & P_{n n}\end{array}\right|, \sum_{j=i}^{n} P_{i j}=1$

where, $X_{m b}$ and $Y_{m b}$ are the model estimated bankline, and $X_{a b}$ and $Y_{a b}$ are the actual bankline in $X$ (time) and $Y$ (position) coordinates the sample points.

3.4 LULCchange analysis: In this study, five Landsat images were used for 1972 (MSS), 1987(TM), 1998(TM), 2008(ETM+), and 2020(OLI) for estimation of LULC imprints of the study area. For analysis of LULC change, the existing bank landscape of the study area were classified into six classes such as i) waterbodies, ii) dense forest, iii) open forest, iv) agricultural land v) built-up area and vi) fallow land. Maximum likelihood algorithm, very useful and common method of supervised classification (Debnath et al., 2017, Wang et al., 2020, Du et al., 2020) is used for this classification attempt in ArcGIS environment.Numerous LULC change detection techniques are successfully used for monitoring land-use temporal variation (Kaufmann and Seto, 2001;Maviza and Ahmed, 2020). In this method, an array of "from-to" matrix like, pixel conversion matrix, area conversion matrix, and percentages conversion matrix were developed on a pixel-by-pixel basis.

3.4.1 Prediction of LULC Change Using CA-Markov Model:The stochastic based CA Markov model, a popular model for LULC changes prediction has been employed by theTerrSet software package. CA filter along with Markov chain strategy developed CA model. The CA model can be stated as follows:

$$
S(t, t+1)=f(S(t), N)
$$

where, $\mathrm{S}$ is the set of limited and discrete cellular states, $\mathrm{N}$ is the Cellular field, $\mathrm{t}$ and $\mathrm{t}+1$ indicates the different times, and $f$ is the transformation rule of cellular states in local space. Markov model is depicted of LULC change predication of following mathematically conditional probability formula.

$$
S(t+1)=P_{i j} \times S(t) \quad \text { (Eq. 11) }
$$

where, where, $\mathrm{S}(\mathrm{t}), \mathrm{S}(\mathrm{t}+1)$ are the system status at the time of $\mathrm{t}$ or $\mathrm{t}+1 ; P_{i j}$ is the transition probability matrix in a state which is calculated as follows: period, and $P_{i j}$ denote the probability from land use and land cover type i to land type $\mathrm{j}$. 
In this expression, ' $\mathrm{n}$ ' is the number of land use and land cover types in the target area, and " $P_{i j}$ " is the probability of transition of type $\mathrm{i}$ into that of type $\mathrm{j}$ from the initiation to the end. In the transition matrix, it requests that each line factor 0 to 1 and each rate is a non-negative quantity. The estimate of the Markov chain is the relative frequency of transitions recognized whole time span and the result of the estimation can be used for prediction (Mondal et al., 2016). In this study, three future years are predicted such as 2020, 2025, 2035 and 2045.

The transition probability matrix has been calculated for the time span of 1972-1987, 1987-1998, 19982008, and 2008-2020 for the prediction of LULC of 2020. The cross-tabulation of two LULC images from each class to every other class is performed in the transition probability matrix.The transition probability areas matrix documents the number of pixels that are expected to change over a particular time period.

3.5 Model validation and evaluation: DSAS model has been used for estimating the future riverbank erosion-accretion, shifting and future bankline position. But before the future prediction, the model has been validated with the current circumstances (Mukhopadhyay et al., 2012; Jana, 2019).To predicate the rate of river riverbank erosion-accretion/shifting and future bankline position, the EPR model is employed between bankline position of 1972 (old) and 2020 (recent). The position of the predicted (Y) bankline (2020) is calculated using the rate of riverbank shifting $\left(\beta_{E P R}\right)$, time interval $\left(X_{o b}-X_{r b}\right)$, between previous $\left(Y_{o b}\right)$ and resent $\left(Y_{r b}\right)$ bankline position and model intercept $\left(\alpha_{E P R}\right)$, which is expressed in the Eq. 13.

$$
Y=\alpha_{E P R}+\beta_{E P R}\left(X_{o b}-X_{r b}\right) \quad \text { (Eq. 13) }
$$

Therefore, the LRR method is employed to future bankline position prediction based on EPR (slope), interval, and intercept value. Based on this, the estimated backline position of 2020 is calculated and the predicted bankline is verified with the actual bankline demarcated from the satellite image of 2020.

Table 2: Zone wise DSAS model-based results of RMSE.

The allover bankline positional error is also verified with $100 \mathrm{GCPs}$, collected from the field survey. RMSE and t-test are adopted for the model validation of in estimated banklines (left and right), which gives an accuracy between actual and predicted banklines. The positional errors at each transect point are placed by error vectors and the bankline shifting varies from $0.007 \mathrm{~m}$ to $0.176 \mathrm{~m}$ (Table 2) with the overall mean error of $0.05 \mathrm{~m}$. The t-test results reveal that the model has good prediction capacity $(\mathrm{p}<0.05)$. So, 279 position (Table 3) 
Table 3:Results of student's t-test based on DSAS model for different zones.

280

281

282

283

284

285

286

287

288

289

290

291

292

293

294

295

296

297

298

299

300

301

302

303

304

305

306

307

Thus, 100 field observation data were collected from both banks for the verification of 2020 bankline position. After that the predicted banklineposition of 2025 was compared with actual (2020) bankline position for better assessment the shifting behavior of Kaljani River.

In this study, the kappa index (Congralton, 1991and Keshtkar, et al., 2017) and chi-square $\left(\chi^{2}\right)$ test (Nath et al., 2020) statistics were developed for the accuracy validation of LULC images. The kappa coefficient the legibility and imagery accuracy were tested to compare them with the actual points from field verification and high-resolution Copernicus satellite data. The kappa coefficient was calculated using the following formula (Congalton and Green, 2009);

Kappa coefficient $=\frac{\sum_{i=1}^{k} n_{i i}-\sum_{i=1}^{k} n_{i i}\left(G_{i} C_{i}\right)}{n^{2}-\sum_{i=1}^{k} n_{i i}\left(G_{i} C_{i}\right)}$

where, $i$ is the class number, $n$ is the total number of classified pixels that are being compared to actual data, $n_{i i}$ is the number of pixels belonging to the actual data class $i$, that were classified with a class $i$, $C_{i}$ is the total number of classified pixels belonging to class $i$ and $G_{i}$ is the total number of actual data pixels belonging to class $i$.

According to the classification accuracy test results, the Kappa statistics for the years, 2020 is 87.57 per cent. The level of agreement indicates that the classification and prediction LULC maps are acceptable. For the chi-square $\left(\chi^{2}\right)$ test, the actual land use of 2020 has compared with the predicted 2020 land use based on the CA-Markov model (Nath et al., 2020). We assume that the area statistics of the predicted and the actual image are the same. Table 4 depicts the chi-square $\left(\chi^{2}\right)$ test result values that indicate the validation and acceptance of the CA-Markov model for the LULC maps prediction.

Table 4: Validation of change prediction based on actual and predicted 2020 LULC image.

\subsection{DSAS based riverbank migration/erosion-accretion rate:The Kaljani River entire course was} segmented into three distinct zones (A, B, and C) by spacing around $26 \mathrm{~km}$ (Fig. 1) based on the axial length of river stretch and meander nature for the intensively explain the model result. Afterward, around 350 transects (on both banks) are generated in the zone A, B, and C for the estimation of riverbank migration/ erosion-accretion rate. The riverbank shifting trend is estimated (Fig. 4 and 5) by considering 
the entire 48 years data $(1972-2020)$. The result depicts in 1972-1987 that the average rate of bankline shifting in zone $\mathrm{A}$ is $4.61 \mathrm{~m} / \mathrm{y}$ and left and right bank is $4.22 \mathrm{~m} / \mathrm{y}$ respectively.In zone $\mathrm{B}$, the rate of average bankline shifting is $0.57 \mathrm{~m} / \mathrm{y}$ (left bank) and $5.88 \mathrm{~m} / \mathrm{y}$ (right bank). The rates of average bankline shifting in zone $\mathrm{C}$ is $2.59 \mathrm{~m} / \mathrm{y}$ and $2.0 \mathrm{~m} / \mathrm{y}$ for the left and right bank, respectively. $-40.86 \mathrm{~m} / \mathrm{y}$ and $44.24 \mathrm{~m} / \mathrm{y}$ are the erosion and accretion in left bank and $-39.66 \mathrm{~m} / \mathrm{y}$ and $43.03 \mathrm{~m} / \mathrm{y}$ in the right bank. In this period, the overall average shifting of the left and right bank is $2.54 \mathrm{~m} / \mathrm{y}$ and $2.00 \mathrm{~m} / \mathrm{y}$, respectively, and the positive shifting (accretion) is observed on both banks in the zone of $\mathrm{A}, \mathrm{B}$ and $\mathrm{C}$. The erosionaccretion rate and no of transect indicate the channel narrowing caused by sediment accretion in both bankline. But both (erosion-accretion) rates are high in left and right bank. Therefore, the dynamicity of the river is very high, especially in zone A compare to other zones.

During the 1987-1998, the average channel migration rate in zone A is $4.21 \mathrm{~m} / \mathrm{y}$ for left bank and 13.22 $\mathrm{m} / \mathrm{y}$ for right bank.In this zone, the spatial distribution of transects that accretion is 205 (left bank) and 190 (right bank), which also indicates the channel narrowing due to sediment accretion on both banks.In zone $\mathrm{B}$, the rate of average shifting is $-0.16 \mathrm{~m} / \mathrm{y}$ for left bank and $1.03 \mathrm{~m} / \mathrm{y}$ for right bank. The channel migrates towards the left bank due to more erosion on the left side (207 transects out of 380 transects) and accretion on the right side (171 transectsout of 380 transects). Zone $\mathrm{C}$ resulted in an average rate of channel migration is $1.13 \mathrm{~m} / \mathrm{y}$ and $-0.10 \mathrm{~m} / \mathrm{y}$ for the left and right bank, respectively. In this zone river move the right side due to more erosion on right bank (219 transectsout of 420 transects). In this time frame, the overall average channel migration rate is 1.13 (left bank) and -0.10 (right bank),respectively. In this regard, at the right bank an extensive erosion experiences and a disproportionate sedimentation (accretion) along the right bank.

Fig. 4 DSAS model derived riverbank migration rate (accretion erosion) during the periods of (a) 1972 - 1987, (b) 1987 - 1998, (c) 1998 - 2008, and (d) 2008-2020 at three selected zones (A, B, and C).

During the 1998-2008, in zone A, the average riverbank migration rate is $8.23 \mathrm{~m} / \mathrm{y}$ (very high accretion) on the left and $-1.50 \mathrm{~m} / \mathrm{y}$ (erosion) on the right bank. It indicates the channel shift towards the right (erosion) and the left bank observe hug accretion condition. The zone B comprises significant accretion in $4.47 \mathrm{~m} / \mathrm{y}$ on the left bank and $11.44 \mathrm{~m} / \mathrm{y}$ on the right bank (Fig. 4). Therefore, the river channel is narrowing by inward sedimentation. In addition, zone $\mathrm{C}$ passes through a relatively higher rate of erosion at the rate of $4.48 \mathrm{~m} / \mathrm{y}$ and $-3.84 \mathrm{~m} / \mathrm{y}$ on the left and right bank, respectively. The correspondences of high erosion at both banks are indicating the channel widening. In this period, overall negative (erosion) trend on the both bankline, which are about $-4.48 \mathrm{~m} / \mathrm{y}$ and $-3.48 \mathrm{~m} / \mathrm{y}$ at the left and right, respectively (Fig. 4). This result indicates the river course widening triggered by persistent erosion on the both banks. 
In the time frame 2008-2020, zone A observes a higher rate of erosion on both banks $(-0.23 \mathrm{~m} / \mathrm{y}$ at left bank and -3.79 at the right bank) with the 209 in left and 186 in right, out of total 350 transects. This result explores leads channel widening through the river channel shifting.In zone $\mathrm{B}$, high accretion $(2.54 \mathrm{~m} / \mathrm{y})$ is recorded in the left bank and high erosion $(-2.83 \mathrm{~m} / \mathrm{y})$ in the right bank. This zone also conforms the shifting of the channel towards the right bankline in response of higher rate of erosion on the right and a relatively meager rate of accretion on the left bankline. The zone $\mathrm{C}$ shows the leftward shifting of the river course with an average riverbank shifting rate of $-0.44 \mathrm{~m} / \mathrm{y}$ at the left bank and $2.12 \mathrm{~m} / \mathrm{y}$ at the right bank. The nature of river shifting indicates the leftward shifting of channel.In general, during the period 2008-2020, the overall migration rate is $-0.44 \mathrm{~m} / \mathrm{y}$ at the left bank and 2.44 at the right bank, which indicates the leftward shifting of the river channel (Fig. 5).As a result, the river channel migrates towards the left bank with large extents of sedimentation at the right bank.

Fig. 5 Distribution of DSAS model derived riverbank erosion and deposition rate along transects during the different study periods, (a)1972-1987, (c) 1987-1998, (e) 1998-2008, (g) 2008-2020, (i) 2020-2025, (k) 2020-2035 and (m) 2020-2045 at the left bank and (b)1972-1987, (d) 1987-1998, (f) 1998-2008, (h) 2008-20202, (j) 2020-2025, (l) 2020-2035, and (n) 2020-2045 at the right bank.

\subsubsection{Model based prediction of banklineshifting}

The result depicts in the Short-term prediction(from 2020 to 2025)that the average rate of bankline shifting in zone A was $-2.61 \mathrm{~m} / \mathrm{y}$ and left and right bank was $4.37 \mathrm{~m} / \mathrm{y}$ respectively.In zone $\mathrm{B}$, the rate of average bankline shifting is $-1.07 \mathrm{~m} / \mathrm{y}$ (left bank) and $4.69 \mathrm{~m} / \mathrm{y}$ (right bank). The rates of average bankline shifting in zone $\mathrm{C}$ is $-2.09 \mathrm{~m} / \mathrm{y}$ and $3.04 \mathrm{~m} / \mathrm{y}$ for the left and right bank, respectively. In this period, the overall average shifting of the left and right bank is $-1.90 \mathrm{~m} / \mathrm{y}$ and $4.00 \mathrm{~m} / \mathrm{y}$, respectively, and the negative shifting (erosion) is observed on left bank in the zone of A, B and C.The predicted bankline in 2025 is validated with the help of an empirical data from field survey (2018 to 2020) and image-based (2020) assessment (Fig. 6). Therefore, the ability of the model in evaluation and validation is stretch with field observation.

Fig. 6 Spatial pattern of bankline migration after prediction in the year 2020, 2025, 2035, and 2045.

The result of the medium-range prediction (from 2020 to 2035) of the average channel migration rate in zone A was $-3.15 \mathrm{~m} / \mathrm{y}$ for left bank and $2.78 \mathrm{~m} / \mathrm{y}$ for right bank.In zone $\mathrm{B}$, the rate of average shifting was $0.22 \mathrm{~m} / \mathrm{y}$ for left bank and $4.53 \mathrm{~m} / \mathrm{y}$ for right bank. Zone $\mathrm{C}$ resulted in an average rate of channel migrationwas- $0.18 \mathrm{~m} / \mathrm{y}$ and $0.55 \mathrm{~m} / \mathrm{y}$ for the left and right bank, respectively. In this time frame, the overall average channel migration rate was $-0.96 \mathrm{~m} / \mathrm{y}$ (left bank) and $2.56 \mathrm{~m} / \mathrm{y}$ (right bank), respectively.

367 This result is equiponderant to the intermediate rates of bankline shifting through erosion-accretion 
between the predicted bankline of 2025 and 2035 (Fig. 6).From 2020 to 2045 predicted of bankline migration (Fig. 6) resulted that in zone A, the average riverbank migration rate was-5.36m/y (very higherosion) on the left and $1.47 \mathrm{~m} / \mathrm{y}$ (accretion) on the right bank. It indicates the channel shift towards the leftbank (erosion) and the right bank observe accretion condition. The zone B comprises significant erosion in $-0.55 \mathrm{~m} / \mathrm{y}$ on the left bank and $3.51 \mathrm{~m} / \mathrm{y}$ on the right bank (Fig. 4). In addition, Zone $\mathrm{C}$ resulted in an average rate of channel migrationwas $0.26 \mathrm{~m} / \mathrm{y}$ and $-0.39 \mathrm{~m} / \mathrm{y}$ for the left and right bank, respectively. In this period, overall negative (erosion) trend on the left bankline, which are about $-1.77 \mathrm{~m} / \mathrm{y}$ and $1.48 \mathrm{~m} / \mathrm{y}$ at the left and right, respectively.It is also recorded that the absolute bankline migration in the Kaljani River is significant and as high as for the intermediate predicted period from 2035 to 2045. Therefore, to a large extent erosion and accretion overreach between the actual and predicted bankline positions between 2020 and 2045. In this regard, at the left bank an extensive erosion experiences and a disproportionate sedimentation (accretion) along the right bank. However, such kind of bankline migration may become exceptional and extensive in the future due to the varied nature of different drivers of bankline erosion and accretion process. The overall result of the predicted bankline represents that the bulky expansion will occur along the left bank and sediment accretion will take place at the right bank. Based on the overlaid analysis of bank shifting and mouza distribution, the result suggests that the Uttar Paitkapara, JaigirChilakhana, Chhatoa, Kaljani, Bhelapeta, Dakshin Latabari, Nimtijhora Tea Garden, Kholta, Chalnipak, BhelakopaDwitia khanda, Ambari, Dakshin Paitkapara, Chalnipak, and AmlaguriDwitia khanda mouzas are a threat to erosion, which is captured in the actual rate of change relevant to predict the future riverbank position. Also, the accretion process is active in the Kholta, Ambari, Dakshin Paitkapara, Chengpara, Bhuchungmari, JaigirChilakhana, Uttar Paitkapara, Chapatali, AiraniChitalia, Chhatoa, Paschim Salbari, Pukuritola, Dhopguri, BholarDabri (CT), Amlaguri, and GabaurBachhra mouza. The Ambari and JaigirChilakhana mouza are the most dynamic mouzas for both erosion and accretion effects.

4.2 Temporal variationof LULC:The temporal variation of LULC categories for the year 1972, 1987, 1998, 2008, and 2020 are depicted in fig. 7. Table 6,illustrates the LULC change of Kaljani River adjacent village area.In 1972 about 6.34 percent , 21.62 percent, 29.18per cent, 26.20per cent, 4.67per cent, and 11.98per cent area were covered by water body, dense forest, open land, agriculture land, built up area, and fallow land respectively, whereas in 1987 these areas were changed to 8.16 per cent, 19.90per cent, 24.25per cent, 28.44per cent, 6.68per cent, and 12.58per cent area respectively, as in 1998 about 5.17per cent, 16.06per cent, 29.88per cent, 30.13per cent, 7.07per cent, and 11.70per cent area 
8.72 per cent, area respectively, as in 2020 about 3.33 per cent, 13.37 per cent, 31.08 per cent, 34.07 per cent, 10.09 per cent, and 8.06 per cent, area respectively.

Table 5: LULC classes of the study area from 1972-2020.

There has been a significant increasing trend for agricultural land, open forest, and built-up area; whereas a decreasing trend was observed for water bodies, dense forest, and fallow lands. The change of all six classes from 1972 to 1998 was very high when compared with the change between 1998 and 2020. A gradual increase rate from 1987-1998, 1998-2008, and 2008- 2020 in open forest, agricultural andbuilt-up area was observed, while water bodies and dense forest were decreasing rapidly (Table. 6). the area matrixes of the different LULC types throughout the given period of investigation, revealsthat the dense forest and water bodies have been convertedinto other land classes; especially water bodies converted to agricultural land, built-up area, and fallow land gradually.

Fig. 7: LULC changes maps of the years (a) 1972, (b) 1987, (c) 1998, (d) 2008, (e) 2020, (f) predicted 2020, (g) predicted2025, (h) predicted2035, and (i) predicted2045.

4.2.1Predicted LULC 2025, 2035, and 2045: The transition probability matrix is generated using LULC maps of 2008 and 2020.These results are used for LULC prediction maps (2020, 2025, 2035, and 2045) by the CA-Markov method (Fig. 7). This work has revealed that if the present spatio-temporal LULC change trends continue, only 12.91 per cent of the total dense forest land will remain by 2045.The predicted results of spatio-temporal LULC dynamics represents that agricultural land in the study area will continue to expand up to 35.49 percent, 36.23 percent, 36.74 percent, whereas, the built-up area 10.47 percent, 10.57 percent, 10.62 per cent by 2025, 2035, and 2045 respectively. Table 7 is the data table which is generated based on the predictive LULC maps output in 2025, 2035 and 2045. Generally, in 2025, 2035, and 2045 the water bodies, dense forest, fallow land was gradually decreased, and the remaining land classes agricultural land, built-up area, open forest area was gradually increased in the future. An overall change in LULC in all the 27 years of estimation expressed that; the agricultural land will dominate by occupying 36.74 per cent $\left(175.92 \mathrm{~km}^{2}\right)$ of the Kaljani River adjacent village area followed by open forest, which was covered 29.98 per cent $\left(143.56 \mathrm{~km}^{2}\right)$.

Table 6: Predicted LULC in 2020, 2025, 2035, and 2045.

\section{Discussion}

The Kaljani River continuously changed its buffer area's LULC through the erosion-accretion process with time. The river bank erosion and accretion are strongly related to river migration and channel expansion. This study shows that from 1972 to 1998, the large-scale bank erosion-accretion and channel 
migration took place due to the extreme flood in the Kaljani River(Rudra and Basu 2002, Mukhopadhyay et al. 2005).In this river course, both banks from zone ' $A$ ' are worse affected parts and areas located in Jaigirchilakhana, Chilakhana, Bhelakopadwitia khanda, Amlaguri, Bhelapeta, Panisala mouzas have experienced a large amount of erosion-accretion and channel migration. The result of erosion and accretion represents that channel widening takes place in this zone through continuous and overturning erosion. After 1998, the nature of bank erosion and accretion has changed due to the occurrence of low magnitude floods. Similarly, the result founds in land utilization from 1972 to 1998 and after 1998 the change has gradually decreased. On the other hand, zone ' $\mathrm{B}$ ' and ' $\mathrm{C}$ ' are comparatively low effected area where the LULC also has least altered. The adjustment of LULC in the adjacent village area of the Kaljani River is independently a significant and interesting fact. In this analysis, dense forest and water bodies are reduced over time, which caused the change in channel behavior (Fig. 8). The built-up area and agricultural land have been eroded and converted into accretion land which again used for both built-up and agricultural purposes.But some areas remain as fallow category due to the presence of high percentage of sand deposition that cannot be used for other purposes. The agricultural land and open forest area have been eroded, whereas it becomes accreted that took place in the opposite bank. Owing to riverbank erosion-accretion this type of LULC change is very significant for socio-economic aspects. As a result, local people have to migrate to another place to change their livelihood patterns. Later, with the modification of the socio-cultural environment and adjustment of LULC change a symbiotic ecosystem has been developed in the study area.

Fig. 8. Conversion of water bodies to other LULC classes.

In this investigation, predicted bankline and predicted LULC result reveals that dense forest, settlement, agricultural land, open forest land will face a significant threat due to future of bank. In the present time, changing tectonic activity, population growth, and climate change, which cannot be accurate, predicted the channel migration rate and LULC change rate. But it is included that, riverbank migration and land utilization ideas will supportto improve the river adjacent mouza areafor restoration and management as well as uplift the socio-economic condition of the riparian peoples in the future. Therefore, the output of the predictions in this work could serve not only as spatial guidelines for monitoring future trends of channel migration and LULC dynamics but also to address threats and deterioration of river adjacent village area ecosystems. Moreover, the prediction of the river bankline position and LULC pattern is meaningfully possible by the application of the CA-Markov and DSAS models.

4605.1 Reasons for channel shifting and LULC pattern change:We observed both natural and 461 anthropological dimensions are playing important role to change the river shifting behavior. The channel 462 migration and erosion-deposition of the Kaljani River may be results of various reasons i.e., massive 
floods, flow discharge in the channel, nature of bedload, bar formation within the channel, and in the banks, change of thalweg between the banks, plate tectonics movement, human intervention, etc. In the Kaljani river, the gradual formation of mid-channel bars changes the river flow pattern and influencing erosion-deposition and channel migration rate of both banks (Maiti, 2016). Discharge water fluctuations of different seasons specifically rainy seasons are the origin of the massive and frequent floods every year or every two years.In this study area, extreme rainfall is a very important factor in river dynamicity. The extreme rainfall increases discharge water and sediment rate to the river. These processes can changes bank stability and channel morphology (Vanacker et al., 2005; Wohl, 2006; Struck et al., 2015; Qazi and Rai, 2018). The acquired results displayed that, under the extreme rainfall as well as frequent floods and the geomorphic response to change the rates of channel migration and erosion-deposition. The average annual rainfall of the study region is $3444.05 \mathrm{~mm}$ during the period 1989-2008 (District Disaster Management Report 2009, Government of West Bengal, India). We have studied 20-year rainfall data which presents extreme rainfall events lead to high magnitude floods. Channel migration and erosiondepositions were recorded very high in those years. The floods can trigger sudden changes in the rivers channel. During the floods, huge amount of water and sediment load flow through the river course which has increased the channel migration and erosion-deposition statistics. The Kaljani River has been facing floods almost in every year or every second year (Starkel et al., 2008). The most effective flooding years of the river is 1972 (moderate intensity), 1980 (moderate intensity), 1993 (highest intensity), 1998 (high intensity), 2000 (high intensity), 2002 (high intensity), 2007(low intensity), 2010 (low intensity), 2014 (low intensity), and 2016 (low intensity) (Rudra and Basu 2002, Mukhopadhyay, et al. 2005, Water and Irrigation Division, Govt. of West Bengal, 2007, and annual flood report, Govt. of West Bengal, 2010, 2014, 2016). The magnitudes of the floods are gradually decreasing over time, but some floods are very massive. In 1993, extreme floods occurred that has caused the highest discharge ever for the Kaljani River which was recorded 140234.53 cusecs (3971 cumecs), (WAPCOS. 2003). Thus, itcan be said that flood events are one of most vital factors for the change of channel migration and erosion-deposition rates.

The fluctuations of the sedimentation rate of the different season are the very important factors that contribute to morphological changes in the Kaljani River migration and erosion-deposition (Mandal et. al., 2017). During monsoon in each year excessive sedimentation has uplifted the channel bed of the river and resistance to the free flow of water (Dey and Mandal, 2019). This problem makes the system highly hazardous during rainy season. During this time, huge discharge with massive velocity increases the amount of river water and creates huge pressure on the Kaljani River bank (Maity and Maiti, 2017, Bjorklund, 2015).This study area is the most sensitive zone of geomorphic transition that is clear. Here a lot of geomorphic processes are going on. The Kaljani River is bearing the imprint of active tectonics of the region as they lie in the zone of Himalayan Frontal Fault, the most active thrust belt of Himalayas 
(Das, 2004, Goswami et al., 2012). Tectonic changes are depicted by the responses made in the adjoining morphology of this river behavior. Among the various causes, one of the most important causes of this river dynamicity is tectonic activity. In our analysis, the total erosion is greater than the deposition which, has indicated this river still erodes. The hypsometric curve represents the different stages of the evolution of erosional landform (Strahler, 1952). The basin age can be analyzed through the hypsometric value. The value of hypsometric integral close to 0 is highly eroded and 1 is quietly eroded regions (Schumm, 1956; Strahler, 1952). We have calculated the hypsometric curve integral as 0.13 which indicates the Kaljani river basin is now fall into mature to the old stage. The basin relief and size variations are represented in the long profiles of the river. The distances and elevations were divided by maximum basin relief and the total stream length respectively to define the long profile (Lee \& Tsai, 2010). Thus, the presence of breaks in the river long profile depicts that strong structural effect is somehow present in the river course. The long profile represents that maximum portion of the river basin is included in plain land (Fig. 9). The hypsometric curve value and the long profile properties provide adequate evidence of this river's low energy but the study result is different. This may be due to the energy boost up takes place in the river during extreme rainfall and floods.So further changes are unavoidable which may establish newer difficulties in concluded the reasons for channel migration and erosion-deposition. Therefore, limitation of our research is the absence of discharge data because data of discharge of this river is not available from any governmental or private authorities.

The Soil Conservation Service Curve Number (SCS-CN) method is determined based on soil group, hydrologic conditions, vegetation types, and agricultural treatment (USDA, 1972). They effectively utilized the satellite data to estimate the USDA Soil Conservation Services (SCS) Runoff Curve Number $(\mathrm{CN})$. SCS-CN is a popular rainfall-runoff model that is widely used to estimate direct runoff from small and un-gauged basins. SCS-CN value is ranging from 0 to 100 (Table 8). Zero represents very low runoff and 100 represents very high runoff. River bank erosion is related with the amount of runoff present in the region. River bank becomes vulnerable when presence of vegetation is low and runoff is very high. In this study, highly eroded areas, such as the Uttar Paitkapara, JaigirChilakhana, Chhatoa, Kaljani,

524 Ambari, Dakshin Paitkapara. Chalnipak, and AmlaguriDwitia khanda mouza are depicted as high SCS-

$525 \mathrm{CN}$ values. That indicates the high runoff is the important causes of the Kaljani Riverbank erosion 526 (Fig.09).

Fig. 9. (A) The Soil Conservation Service RunoffCurve Number of the Kaljani River adjacent village areas with field photo, (B)Long profile of the Kaljani River Basin (Modify M. Hasanuzzaman et al., 2021) 
Among the various serious reasons, tectonic activity, climate, flood, and human intervention especially constriction of the embankment along the Kaljani River are the most important reasons for this dynamic changed.The impact of riverbank erosion-accretion, bank margin shifting and erosion protection embankment structure at different river zones has been resulted in the EPR model output. In this investigation, it is observed that a large number of mouzas with immense population pressure are vulnerable, where most of the people are engaged in agricultural activities. Therefore, a large number of embankment installations along the Kaljani River for flood control can be modifiedby the erosionaccretion and adopted LULC patterns.Embankments along the river affect river channel morphology and its flow dynamics. As we know that the man-made embankment increases the stress on the riverbed, so it becomes more vulnerable to erosion than protecting it (Yao et. al. 2011). Thus, it is an important factor for the morphologic changes like the erosion of the river bank and accretion on floodplain. In our study area, the most active banks have been stabilized, especially along the right side. The field survey and Copernicus satellite image show the existence of man-made embankment in 27 places at the right bank and 13 places at the left bank along with 20 bridges (Fig. 10). In the right bank, erosion rate has been decreased because here the contiguity of embankment is largely extended, but left bank experienced more erosion due to shorter length bank embankments. The riverbank erosion-accretion, channel migration, and LULC pattern change observation are a very important variable to planners, environmentalists, policymakers for understanding and formulating the needed and appropriate channel design schemes of vulnerable areas of Kaljani River.

Fig. 10. Bridges and embankment along the Kaljani River with field validation photos.

\section{Conclusion}

This study has demonstrated the application and capability of earth observatory technology and generated a detailed evaluation of temporal and spatial changes in river channel dynamics and adjustment of LULC of the Kaljani River adjacent village area.The multi-temporal data analysis reveals that the Kaljani River has continuously been changed its bankline positions from extensive erosion-accretion processes and modified its adjacent village area LULC pattern significantly.In this river course, both banks from zone 'A' (lower part of the river) are worse affected parts and areas located in Jaigirchilakhana, Chilakhana, Bhelakopadwitia khanda, Amlaguri, Bhelapeta, Panisala mouzas have experienced a large amount of 556 erosion-accretion and its impact on LULC over the study period.The overall result of the predicted 557 bankline represents thatAmbari and JaigirChilakhana mouza are the most dynamic mouzas for both 558 erosion and accretion effects.The study assesses the significant land-use study regarding the dynamic 559 change of river bankline positions in vulnerable areas and the endangered condition of the nearby 560 settlements and infrastructures due to high bank erosion. Most hydrogeomorphological studies are 
561 focused on identifying factors causing the riverbank migration and erosion-accretion and its present

562 situation. Moreover, the longprofile, hypsometric curve value, and the Soil Conservation Service Curve

563 Number (SCS-CN) value have been a significant help in understanding and identification of

564 consequences reasons. This work is a small effort to calculate the historical and future river bankline

565 migration and LULC change patterns through an automated computational platform. Field validation and

566 continuous monitoring are imperative for such types of automated approaches. Therefore, in the present

567 research, the DSAS and CA-Markov based automated approach is employed as an alternative way that

568 successfully and accurately measures and predilections of geomorphic processes (erosion-accretion and

569 LULC patterns) at an appropriate spatio-temporal scale. The level of accuracy is validated by the actual

570 bankline positions (2020) with predicted bankline (2020) and actual LULC (2020) to predicted LULC

571 (2020) empirically. Also, RMSE, and Students t-test (for riverbank migration) and Chi-Square Test,

572 kappa coefficient (for LULC Maps) are adopted for validated this work. Moreover, it will be very much

573 helpful for engineers and planners can the administrators to take the required river adjacent village area

574 management plans and ensure to minimize human intervention and the river adjacent village area heath

575 are healthier.

576

\section{References}

ABBe TB, \& Montgomery, DR(2003) Patterns and processes of wood debris accumulation in the Queets river 579 basin, Washington. Geomorphology, 51(1-3), 81-107. doi:10.1016/s0169-555x(02)00326-4

A80ned F (2012) Detection of change in vegetation cover using multi-spectral and multi-temporal information for 581 District Sargodha, Pakistan. Soc. Nat. 24, 557- 572.

A8Braf M, \& Shakir AS(2018) Prediction of river bank erosion and protection works in a reach of Chenab River, 583 Pakistan. Arabian Journal of Geosciences, 11(7). doi:10.1007/s12517-018-3493-7.

B\&4klund PP(2015)Morphodynamics of rivers strongly affected by monsoon precipitation: Review of 585 depositional style and forcing factors. Sedimentary Geology, 323, 110-147.

586krabarti Goswami, C, Mukhopadhyay D, \& Poddar, BC(2013) Geomorphology in relation to tectonics: A case 587 study from the eastern Himalayan foothills of West Bengal, India. QuaternaryInternational, 298, 80588 92. doi:10.1016/j.quaint.2012.12.020.

58lagalton RG(1991) A review of assessing the accuracy of classifications of remotely sensed data. Remote Sens. 590 Environ. 37 (1), 35-46.

59ingalton RG, Green K(2009) Assessing the Accuracy of Remotely Sensed Data: Principles and Practices, 2nd 592 ed.; Taylor and Francis Group, LLC: Abingdon, UK. 
BQBnath J, Das (Pan) N, Ahmed I, \& Bhowmik M(2017) Channel migration and its impact on land use/land cover 594 using RS and GIS: A study on Khowai River of Tripura, North-East India. The Egyptian Journal of 595 Remote Sensing and Space Science, 20(2), 197-210. doi:10.1016/j.ejrs.2017.01.009.

B 6 6X, Zhao X, Liang S, Zhao J, Xu P, \& Wu D(2020) Quantitatively Assessing and Attributing Land Use and 597 Land Cover Changes on China's Loess Plateau. Remote Sensing, 12(3), 353. doi:10.3390/rs12030353.

D98 JD(2004)Active tectonics of the Eastern Himalayan foothills region and adjoining Brahmaputra Basin based 599 on satellite images, International Journal of Remote Sensing, 25:3, 549-557, DOI: $600 \quad 10.1080 / 0143116031000148070$

bey S, \& Mandal S(2019) Assessing channel migration dynamics and vulnerability (1977-2018) of the Torsa 602 River in the Duars and Tal region of eastern Himalayan foothills, West Bengal, India. Spatial Information 603 Research. doi:10.1007/s41324-018-0213-z

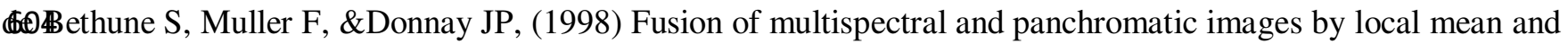
605 variance matching filtering techniques. Fusion of Earth Data, 28-30.

606an A, \& Younis BA, (2009) Prediction of Bank Erosion in a Reach of the Sacramento River and its Mitigation 607 with Groynes. Water Resources Management, 23(15), 3121-3147. doi:10.1007/s11269-009-9426-1.

60\&taugh CS, \&Hasenauer H (2014) Deriving forest fire ignition risk with biogeochemical process modelling. 609 Environmental Modelling \& Software, 55, 132-142. doi:10.1016/j.envsoft.2014.01.018.

G\$Owami C, Mukhopadhyay D, \& Poddar BC(2012)Tectonic control on the drainage system in a piedmont region 611 in tectonically active eastern Himalayas. Frontiers of Earth Science, 6(1), 29-38. doi:10.1007/s11707612 012-0297-z.

G1Bnell AM, Bertoldi W, \&Corenblit D (2012) Changing river channels: The roles of hydrological processes, 614 plants and pioneer fluvial landforms in humid temperate, mixed load, gravel bed rivers. Earth-Science 615 Reviews, 111(1-2), 129-141. doi:10.1016/j.earscirev.2011.11.005

IG⿴囗⿱一一) 617 affected Upper Brahmaputra plains, India, using RS-GIS techniques. Egypt J. Remote Sens. Space Sci. $61818,107-118$.

HAghad R, Balzter H, \&Kolo K (2018) Predicting Land Use/Land Cover Changes Using a CA-Markov Model 620 under Two Different Scenarios. Sustainability, 10(10), 3421. doi:10.3390/su10103421

Eaque SM,Kannaujiya S, Taloor AK, Keshri D, Bhunia RK, Champati Ray PK, Chauhan P (2020) Identification 622 of groundwater resource zone in the active tectonic region of Himalaya through earth observatory 623 techniques, Groundwater for Sustainable Development, Elsevier, Vol. 10. 624 doi.org/10.1016/j.gsd.2020.100337

H25ke JM (1979) An analysis of the processes of river bank erosion. J Hydrol 42:39 62. 
527 S, (2019) An automated approach in estimation and prediction of riverbank shifting for flood-prone middle627 lower course of the Subarnarekha River, India. International Journal of River Basin Management, 1628 49. doi:10.1080/15715124.2019.1695259.

KRAinhans MG(2010) Sorting out river channel patterns. Progress in Physical Geography, 34(3), 287-326.

K30kara RS, Selvan SC, Markose VJ, Rajan B, \&Arockiaraj S(2015) Estimation of Long- and Short-Term 631 Shoreline Changes Along Andhra Pradesh Coast Using Remote Sensing and GIS Techniques. Procedia 632 Engineering, 116, 855-862. doi:10.1016/j.proeng.2015.08.374

Kaßffman S, Droogers P, Hunink J, Mwaniki B, Muchena F, Gicheru P, Bindraban P, Onduru D, Cleveringa R, 634 Bouma J(2014) Green Water Credits-exploring its potential to enhance ecosystem services by reducing 635 soil erosion in the Upper Tana basin, Kenya. International Journal of Biodiversity Science, Ecosystem 636 Services \& Management, 10(2), 133-143.

K3Zhtkar H, Voigt W, Alizadeh E (2017) Land-cover classification and analysis of change using machinelearning 638 classifiers and multi-temporal remote sensing imagery. Arabian Journal of Geosciences. 10(6). 639 https://doi.org/10.1007/s12517-017-2899-y.

6AQlerDW (1993) Themeasurementofriverbankerosionandlateralchannelchange:Areview. EarthSurf. Process. 641 Landf, 18, 777-821.

6Aagat PK, Kumar L, Koech R(2018) Understanding water and land use within Tana and Athi River Basins in 643 Kenya: opportunities for improvement. Sustainable Water Resources Management, 1-11.

6AAgat PK, Kumar L, \&Koech R (2019) Monitoring river channel dynamics using remote sensing and GIS 645 techniques. Geomorphology, 325, 92-102.

1646 CS, Tsai LL (2010) A quantitative analysis for geomorphic indices of longitudinal river profile: a case study 647 of the Choushui River, Central Taiwan. Environmental Earth Sciences 59(7): 1549-1558.

16HBiza A, \& Ahmed F (2020) Analysis of past and future multi-temporal land use and land cover changes in the 649 semi-arid Upper-Mzingwane sub-catchment in the Matabeleland south province of Zimbabwe. 650 International Journal of Remote Sensing, 41(14), 5206 5227. doi:10.1080/01431161. 2020.1731001.

16Einsour S, Al-Awhadi T, Al-Hatrushi S (2019) Geospatial based multi-criteria analysis for ecotourism land 652 suitability using GIS \& AHP: a case study of Masirah Island, Oman. J. Ecotourism 1-20.

I6EFFeeters SK (1996) The use of the Normalized Difference Water Index (NDWI) in the delineation of open 654 water features. International journal of remote sensing, 17(7), 1425-1432.

1655radi G, Rennie C, Vermeulen B, Cardot R, \& Lane S(2018) Secondary circulation in river junctions even at 656 very low flow momentum ratios: The legacy effects of point bar formation.

16507irulAlam GM, Alam K, \& Mushtaq S (2018) Drivers of Food Security of Vulnerable RuralHouseholds in 658 Bangladesh: Implications for Policy and Development. South Asia Economic Journal, 19(1), 43- 63. 
1659hdal MS, Sharma N, Garg PK, \&Kappas M(2016) Statistical independence test and validation of CA Markov 660 land use land cover (LULC) prediction results. The Egyptian Journal of Remote Sensing and Space 661 Science, 19(2), 259-272. doi:10.1016/j.ejrs.2016.08.001.

16Eall AD, Strasser A, Gholami R, Elochukwu H, Fakhari N, \&Sarmadivaleh M(2018) Standards for publications 663 in the field of basin analysis in Earth-Science Reviews. Earth-Science Reviews, 20, 45Z.

166akhopadhyay A, Mukherjee S, Mukherjee S, Ghosh S, Hazra S, \& Mitra D(2012) Automatic shoreline 665 detection and future prediction: A case study on Puri Coast, Bay of Bengal, India. European Journal of 666 Remote Sensing, 45(1), 201-213.

1663hopadhyay SC(2005) Combating Disaster Perspective in the New Millenium, 'Flood and its Management in 668 the Brahmaputra Basin',Edited by- Banerjee, A., Mallick, B., Sarkar, D., Datta, H., Chakraborti, J., 669 Bhattacharya, P., Mandal, R., Mandal, S., Kolkata: acb Publications, pp. 262-270.

16701ti R(2016) Modern approaches to fluvial geomorphology. Delhi: Primus Books.

677andal AC, Patra P, Majumder R, Ghosh DK, \&Bhunia GS(2017) Evaluating meander shifting dynamics (1977672 2017) of the Bhagirathi river course in Murshidabad District, West Bengal, India. Spatial Information 673 Research, 26(1), 33-45.

16124ty SK, \&Maiti R(2017) Sedimentation under variable shear stress at lower reach of the Rupnarayan River. 675 West Bengal, India: Water Science. https://doi.org/10.1016/j.wsj.2017. 02.001.

16765Hasanuzzaman, Amiya Gayen\&Pravat Kumar Shit (2021) Channeldynamics andgeomorphological

677 adjustments of Kaljani River in Himalayan foothills, GeocartoInternational, DOI:

678 10.1080/10106049.2021.1882008

W79h B, Wang Z, Ge Y, Islam KP Singh R, \&Niu Z(2020) Land Use and Land Cover Change Modeling and 680 Future Potential Landscape Risk Assessment Using Markov-CA Model and Analytical Hierarchy 681 Process. ISPRS International Journal of Geo-Information, 9(2), 134. doi:10.3390/ijgi9020134

682wanda A, \&Honjo T(2019) The Prediction of City Expansion and Land Surface Temperature in Bogor City, 683 Indonesia. Sustainable Cities and Society, 101772. doi:10.1016/j.scs.2019.101772.

B844s GE(1995) Changing river channels: the geographical tradition. In: A. Gurnell\& G. Petts (eds.), Changing 685 River Channels. John Wiley \& Sons, New York, pp 1-23.

Q86i NQ, Rai SP, (2018)Spatio-temporal dynamics of sediment transport in lesser Himalayan catchments. India. 687 Hydrolog. Sci. J. 63, 50-62.https://doi.org/10.1080/ 02626667.2017.1410280.

B8\&aldi M, Surian N, Comiti F, Bussettini M (2013) A method for the assessment and analysis of the 689 hydromorphological condition of Italian streams: The Morphological Quality Index (MQI). 690 Geomorphology, 180, 96-108. 
BgAra K(2002) Changing Environmental Scenario of the Indian Subcontinent, 'Floods in West Bengal, 2000 692 Causes and Consequences', Edited by- Basu, S.R., Kolkata: acb Publications, pp. 326-347.

\$eßumm SA(1977) The fluvial system. New York: Wiley.

\$el RJ, \& Milliken KL(2013) Major advances in siliciclastic sedimentary geology, 1960-2012. The Web of 695 Geological Sciences: Advances, Impacts, and Interactions. Geological Society of America, Special 696 Papers, 500, 121-166.

\$Q⿱żz $\mathrm{TM}$, \& Nanson G C(2018) Temporal and spatial adjustments of channel migration and planform geometry: 698 responses to ENSO driven climate anomalies on the tropical freely - meandering Aguapeí River, São 699 Paulo, Brazil. Earth Surface Processes and Landforms, 43(8), 1636-1647.

\$0Daimi HM, Jamal MH, \& Ahmad A (2018) Assessment of river bank erosion at Kilim River, Langkawi using 701 geospatial technique. In IOP Conference Series: Earth and Environmental Science (Vol. 169, No. 1, p. 702 012012). IOP Publishing.

\$0Bck M, Andermann C, Hovius N, Korup O, Turowski JM, Bista R, Pandit HP,Dahal RK(2015) Monsoonal 704 hillslope processes determine grain size-specific suspended sediment fluxes in a trans-Himalayan river. 705 Geophys. Res. Lett. 42, 2302-2308.

\$0rkel L, Sarkar S, Soja R, Prokop P(2008) Present-day Evolution of the Sikkimese-Bhutanese Himalayan 707 Piedmont. PraceGeograficzneIGiPZ PAN. 219.

\$08hler AN(1952) Dynamic basis of geomorphology. Geological Society of America Bulletin, 63, 923-938.

Tåkur PK, Laha C, Aggarwal SP(2012) River bank erosion hazard study of river Ganga, upstream of Farakka 710 barrage using remote sensing and GIS. Nat. Hazards 61, 967-987

Thileler ER, Himmelstoss EA, Zichichi JL, and ErgulAyhan(2009) Digital Shoreline Analysis System (DSAS) 712 version 4.0 - An ArcGIS extension for calculating shoreline change: U.S. Geological Survey Open-File 713 Report 2008-1278.

¿S4A (1972) National Engineering Handbook, Hydrology. US Government Printing Office,Washington, DC, 715 USA.

7æ6acker V, Molina A, Govers G, Poesen J, Dercon G, Deckers S(2005) River channel response to short-term 717 human-induced change in landscape connectivity in Andean ecosystems. Geomorphology 72, 340-353. 718 https://doi.org/10.1016/j. geomorph.2005.05.013.

Wlang S, Mei Y (2016) Lateral erosion/accretion area and shrinkage rate of the Linhereachbraided channel of the 720 Yellow River between 1977 and 2014. Journal of GeographicalSciences, 26(11), 1579-1592.

W2aing B, Xu YJ(2018) Dynamics of 30 large channel bars in the Lower Mississippi River inresponse to river 722 engineering from 1985 to 2015. Geomorphology, 300, 31-44. 
W2ang SW, Gebru BM, Lamchin M, Kayastha RB, \& Lee WK(2020) Land Use and Land Cover Change Detection 724 and Prediction in the Kathmandu District of Nepal Using Remote Sensing and GIS. Sustainability, 12(9), 725 3925. doi:10.3390/su12093925.

W2est Bengal annual flood report(2013; 2014; 2016) Irrigation and Waterways Department, West Bengal, India

W 20 hl E (2006) Human impacts to mountain streams. Geomorphology 79, 217728 248.https://doi.org/10.1016/j.geomorph.2006.06.020.

W2APCOS(2003) Master Plan for Flood Management and Erosion Control in North Bengal, Phase--I (Volume I \& 730 Volume-H), March-2003, Govt. of West Bengal, UttarbangaUnnayan Parshad, Office ofthe 731 Commissioner, Jalpaiguri Division.

X312H(2006) Modification of normalised difference water index (NDWI) to enhance open water features in 733 remotely sensed imagery. International journal of remote sensing, 27(14), 3025-3033.

X3ato M, Wu J, Chen Q, Jin M, Hao X, Zhang Y(2012) Dynamic change of land use in Changhua 735 downstreamwatershed based on CA-Markov model. Transactions of the Chinese Society of Agricultural 736 Engineering. 28(10):231 28 .

Үаб Z, Ta W, Jia X, \& Xiao J (2011) Bank erosion and accretion along the Ningxia-Inner Mongolia reaches of 738 the Yellow River from 1958 to 2008.Geomorphology, 127(1-2), 99 739 106. doi:10.1016/j.geomorph.2010.12.010

YalM, Xie Y, Wu S, \& Tian H(2018) Sidewall shear stress distribution effects on cohesive bank erosion in curved 741 channels. In Proceedings of the Institution of Civil Engineers-Water Management (pp. 1-13). Thomas 742 Telford Ltd. 


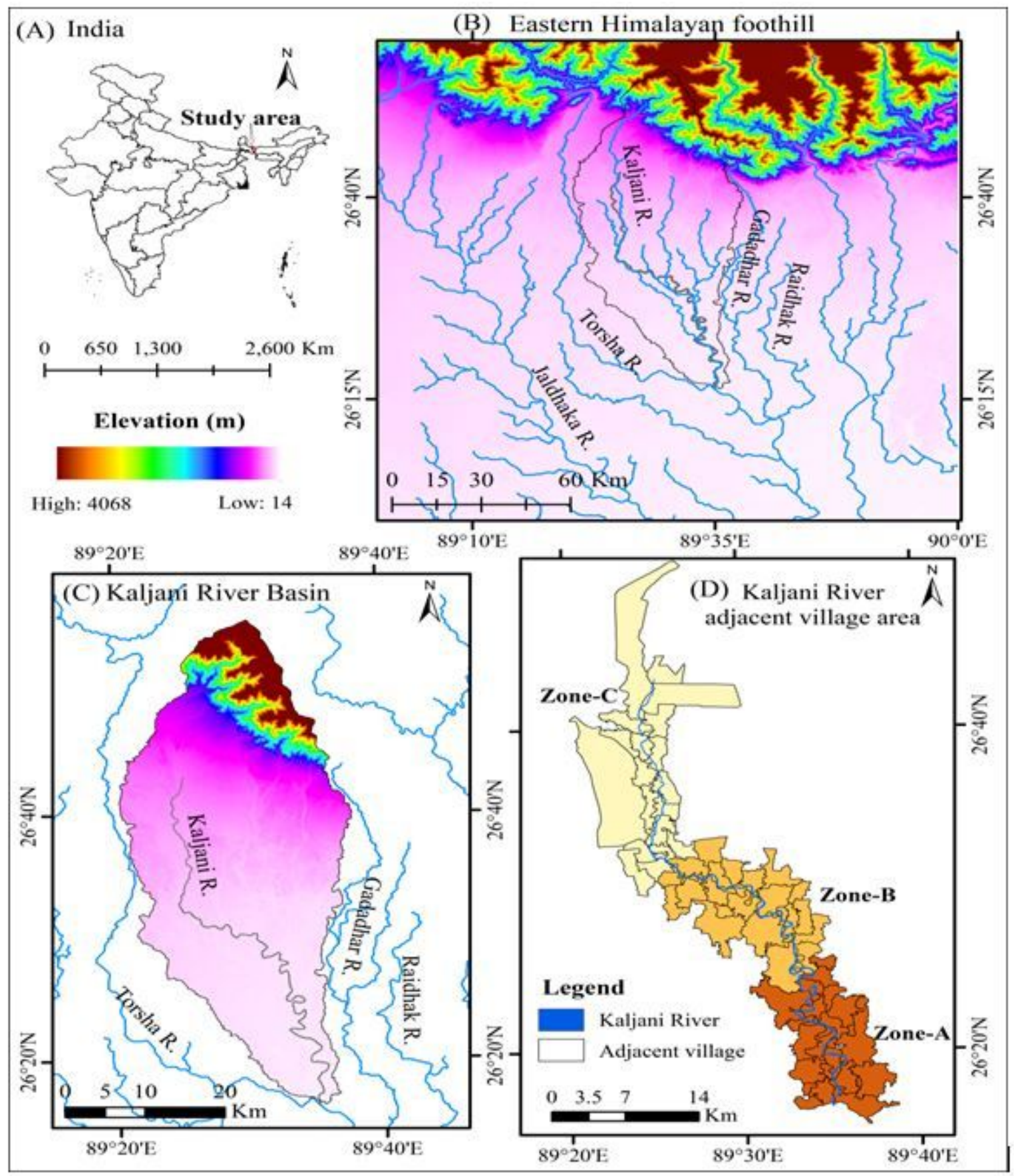

\section{Figure 1}

Location map of the study area (A) India, (B) Eastern Himalayan foothill, (C) Kaljani River Basin with altitude, and (D) Kaljani River Buffer Mouza. Note: The designations employed and the presentation of the material on this map do not imply the expression of any opinion whatsoever on the part of Research Square concerning the legal status of any country, territory, city or area or of its authorities, or concerning the delimitation of its frontiers or boundaries. This map has been provided by the authors. 


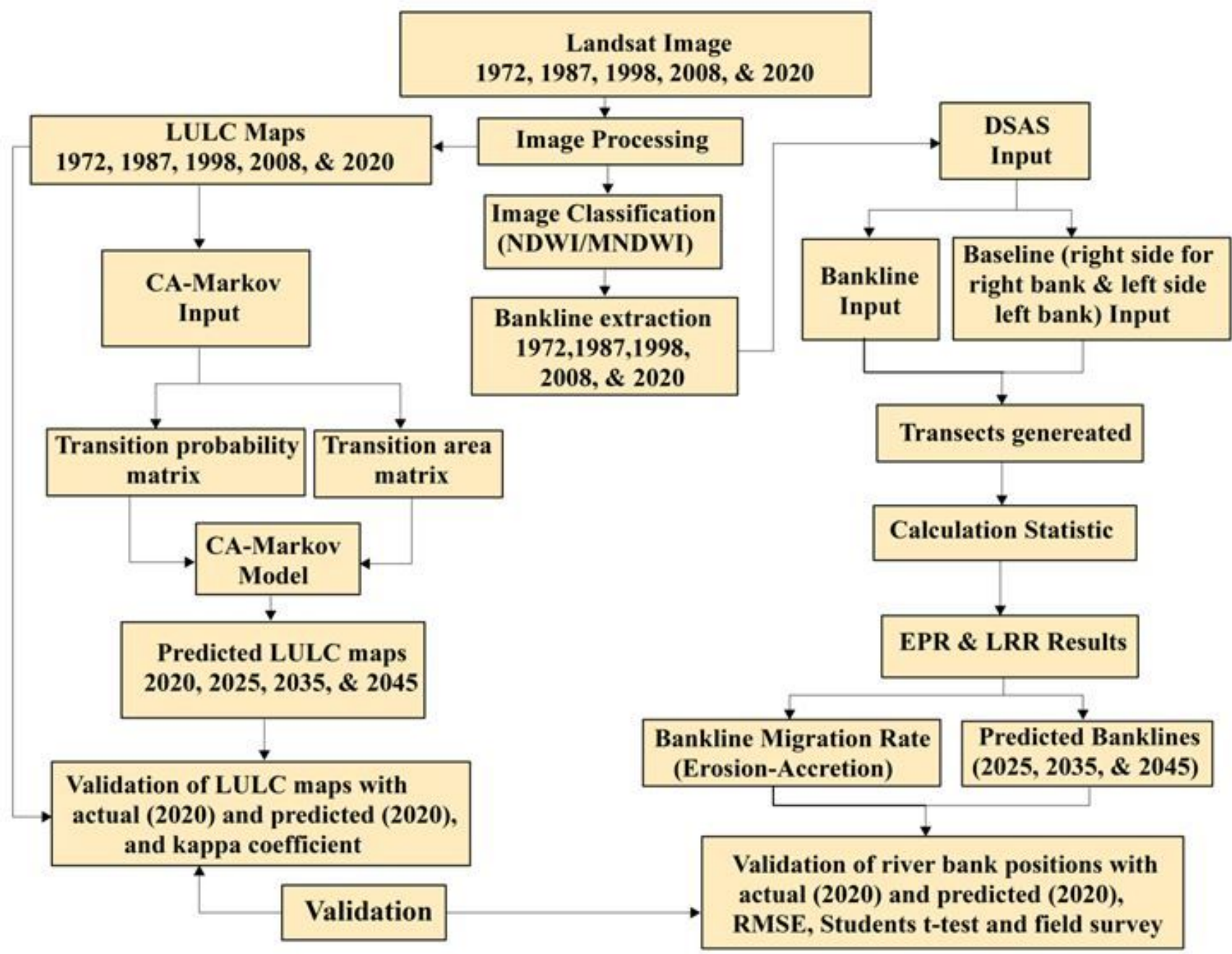

Figure 2

Conceptual framework of the methods used. 


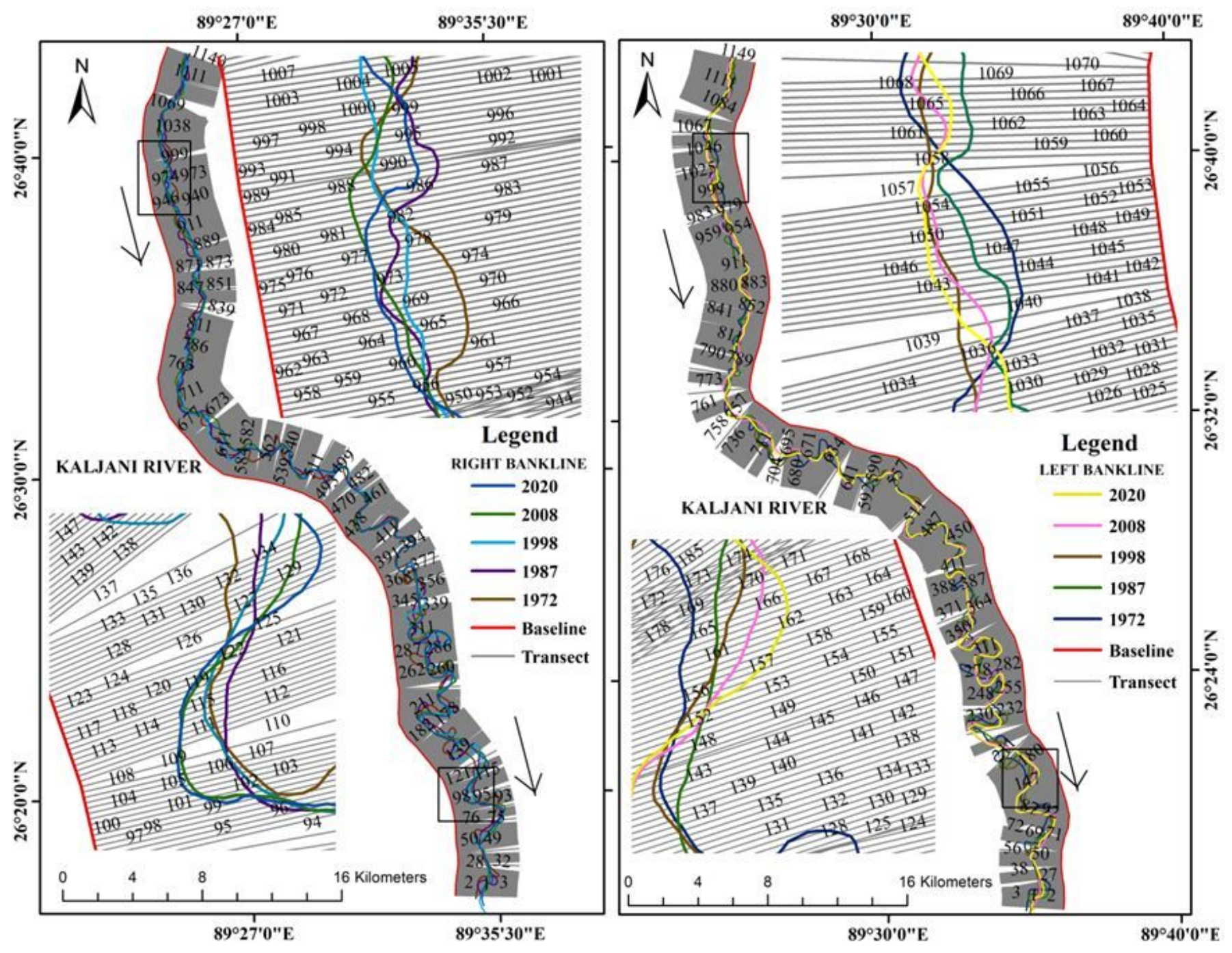

Figure 3

Different banklines (1972 - 2020) are positioned along the baseline. All transects are oriented at angle with the corresponding baselines. 

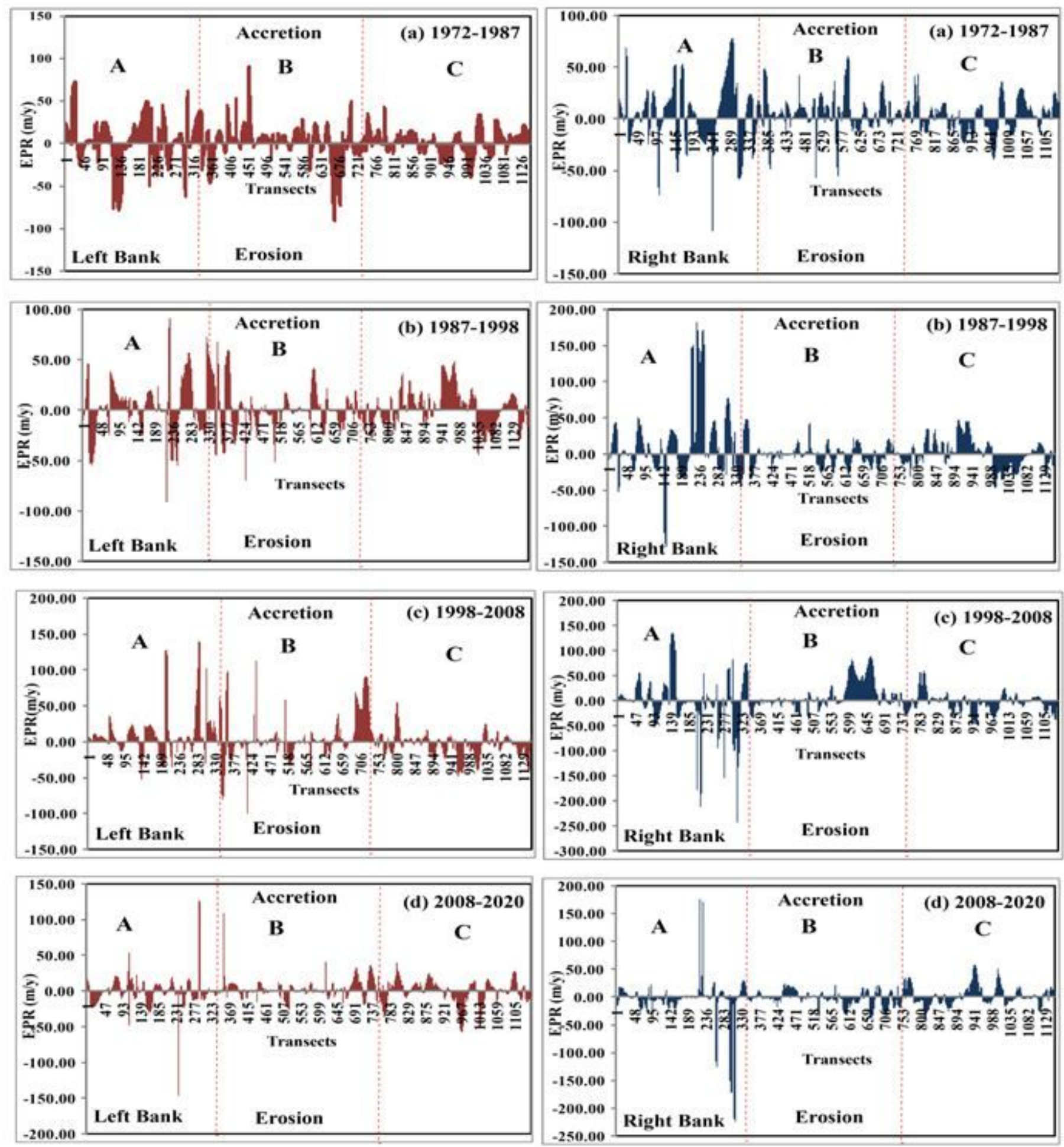

Figure 4

DSAS model derived riverbank migration rate (accretion erosion) during the periods of (a) 1972 - 1987, (b) 1987 - 1998, (c) 1998 - 2008, and (d) 2008-2020 at three selected zones (A, B, and C). 


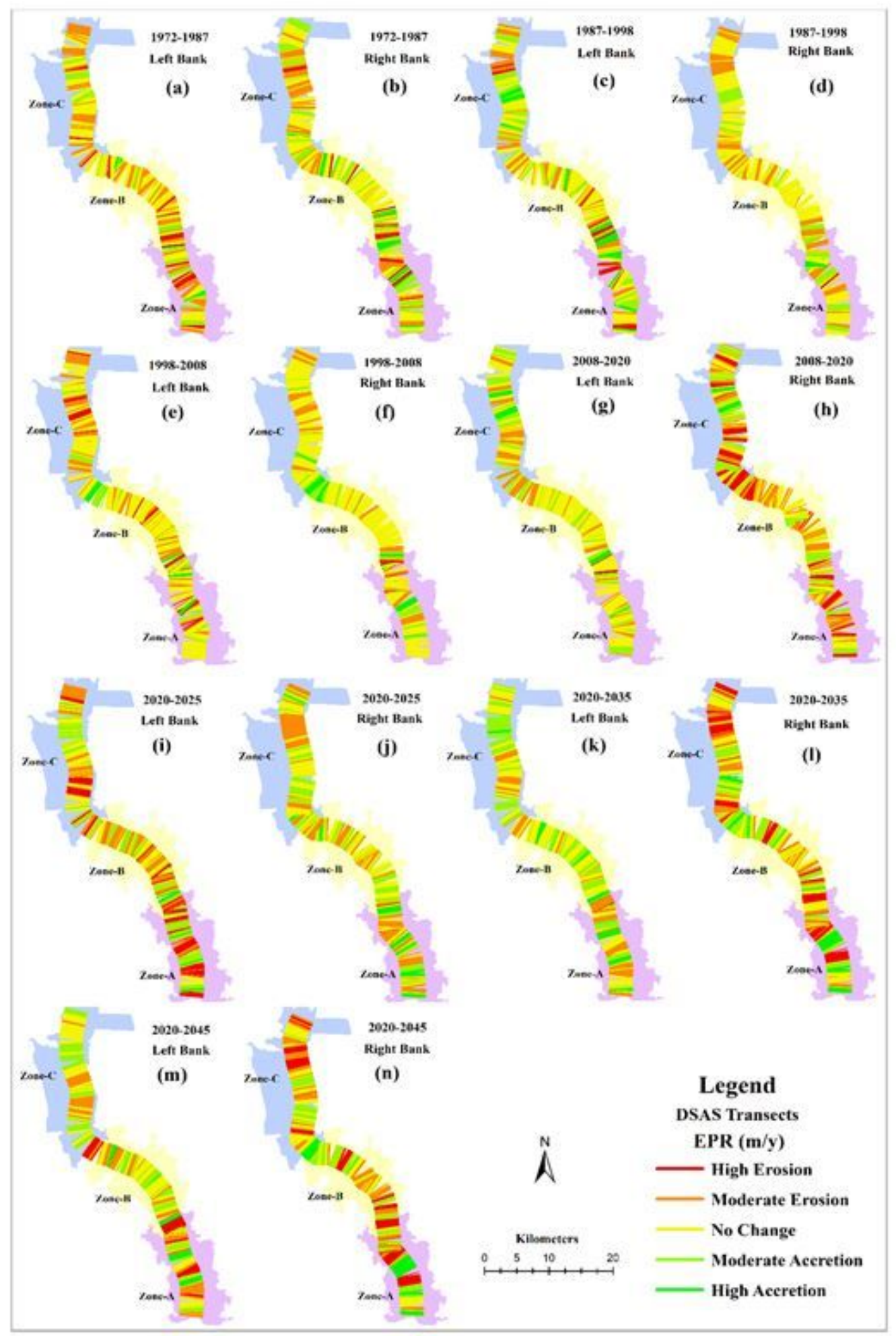

\section{Figure 5}

Distribution of DSAS model derived riverbank erosion and deposition rate along transects during the different study periods, (a)1972-1987, (c) 1987-1998, (e) 1998-2008, (g) 2008-2020, (i) 2020-2025, (k) 2020-2035and (m) 2020-2045 at the left bank and (b)1972-1987, (d) 1987-1998, (f) 1998-2008, (h) 200820202 , (j) 2020-2025, (l) 2020-2035, and (n) 2020-2045 at the right bank. 


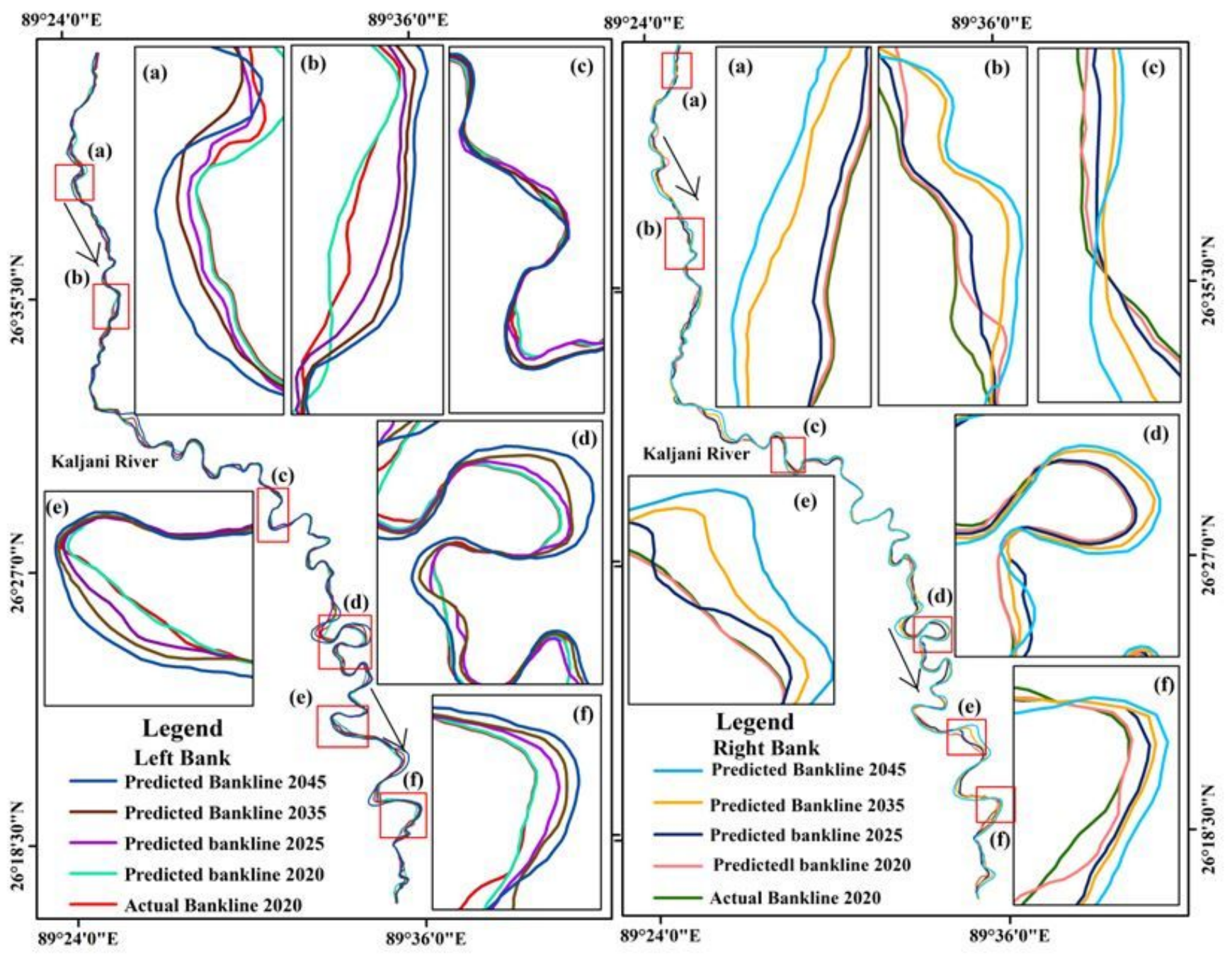

Figure 6

Spatial pattern of bankline migration after prediction in the year 2020, 2025, 2035, and 2045. 


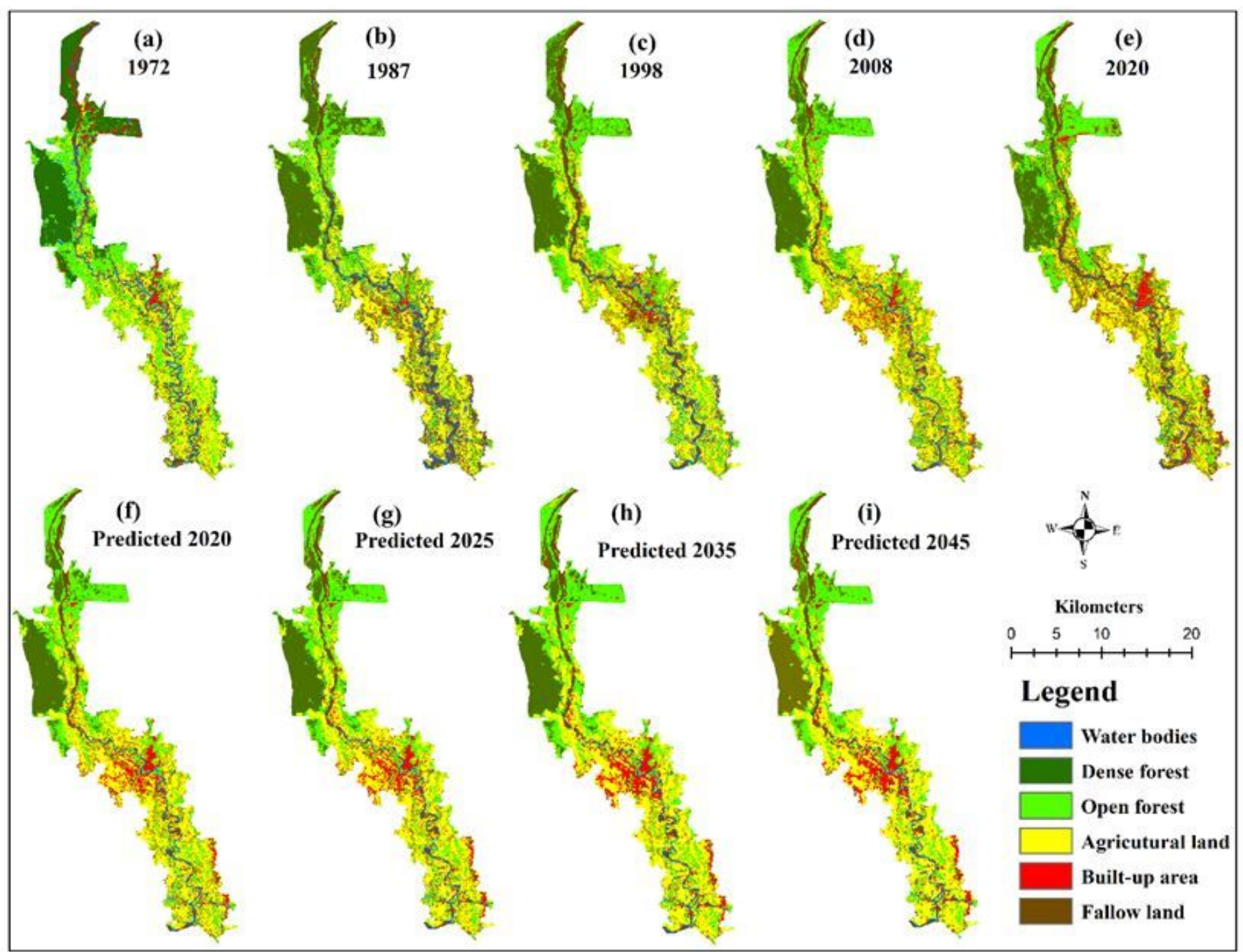

Figure 7

LULC changes maps of the years (a) 1972, (b) 1987, (c) 1998, (d) 2008, (e) 2020, (f) predicted 2020, (g) predicted2025, (h) predicted2035, and (i) predicted2045. 


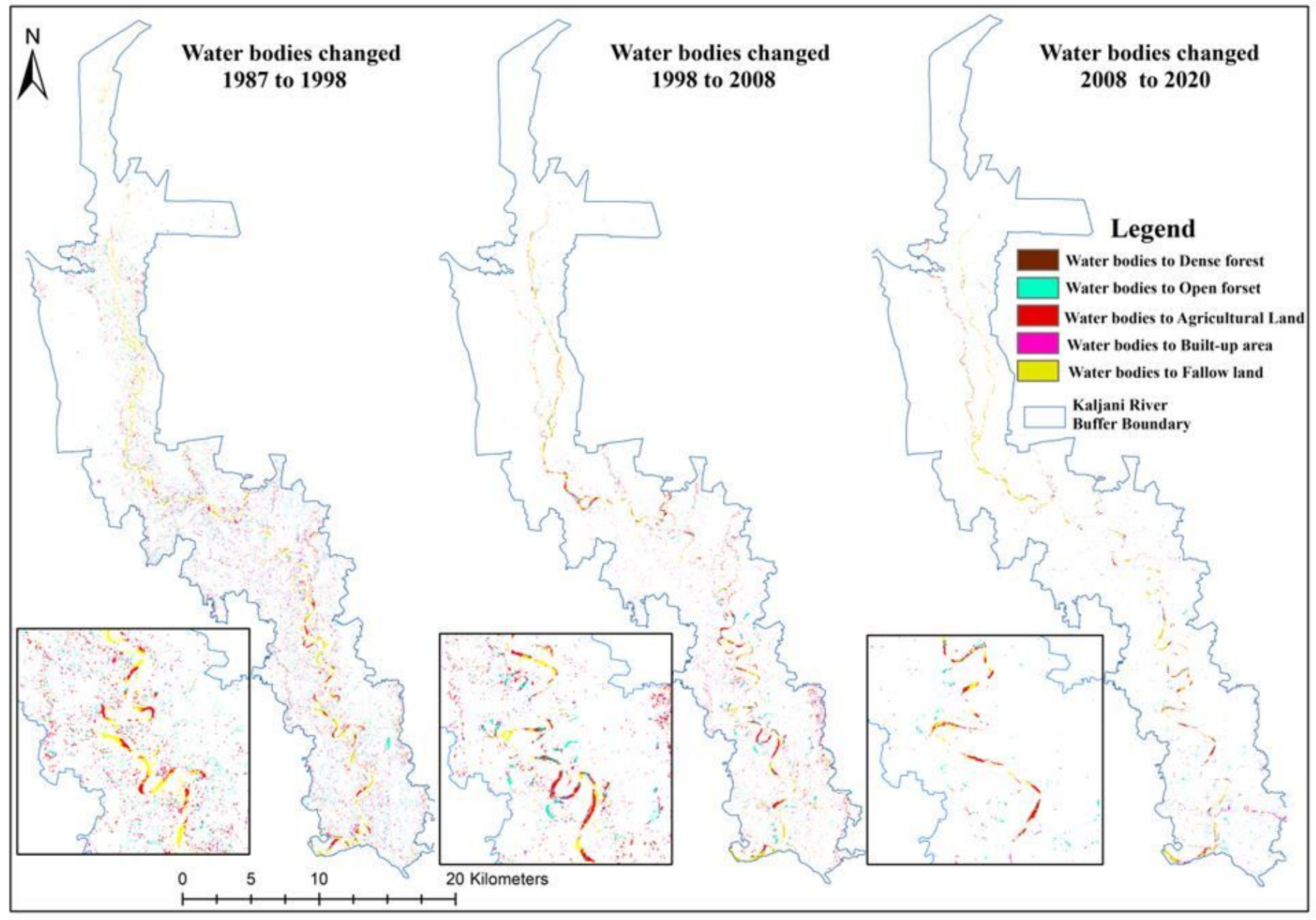

Figure 8

Conversion of water bodies to other LULC classes. Note: The designations employed and the presentation of the material on this map do not imply the expression of any opinion whatsoever on the part of Research Square concerning the legal status of any country, territory, city or area or of its authorities, or concerning the delimitation of its frontiers or boundaries. This map has been provided by the authors. 


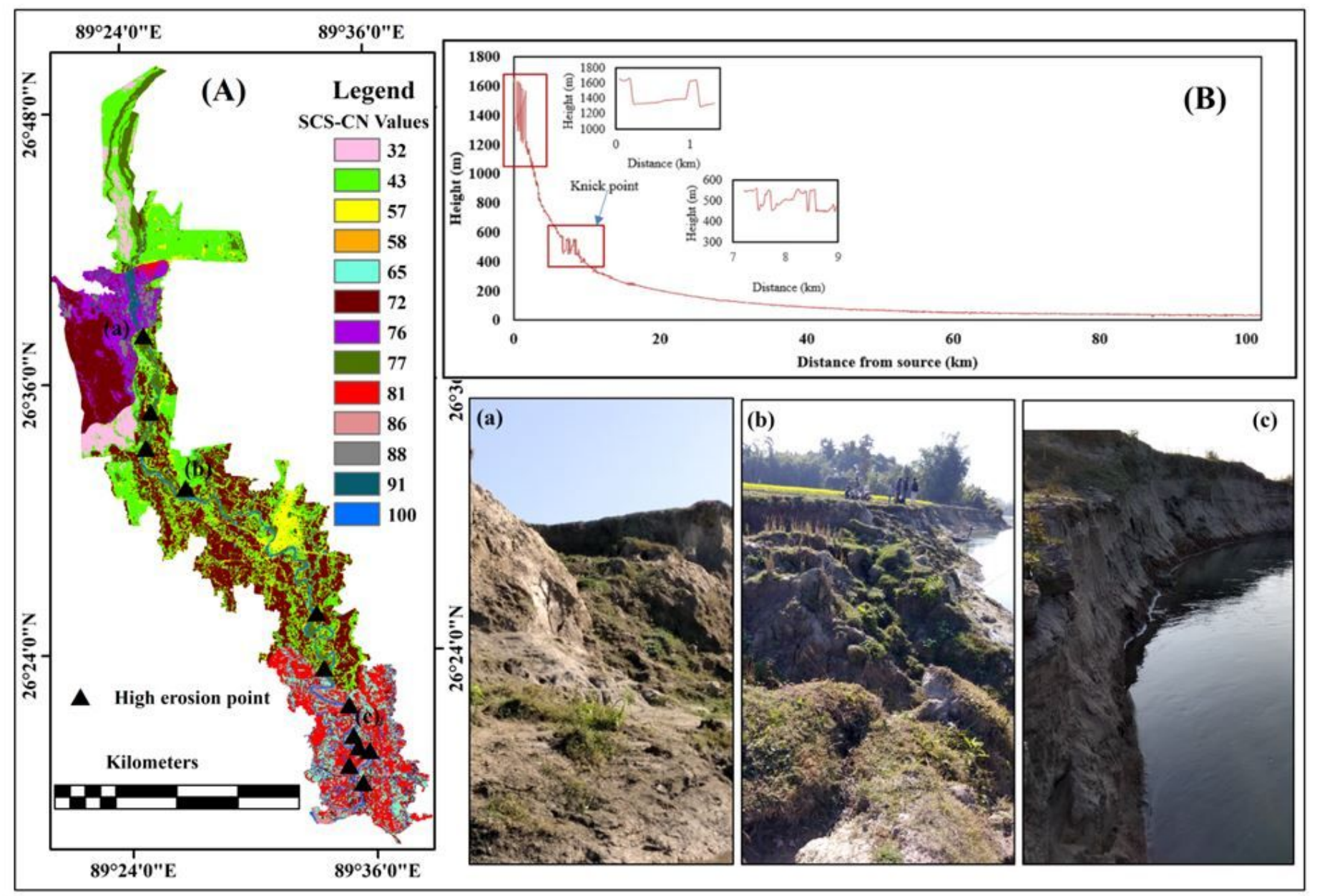

Figure 9

(A) The Soil Conservation Service RunoffCurve Number of the Kaljani River adjacent village areas with field photo, (B)Long profile of the Kaljani River Basin (Modify M. Hasanuzzaman et al., 2021) Note: The designations employed and the presentation of the material on this map do not imply the expression of any opinion whatsoever on the part of Research Square concerning the legal status of any country, territory, city or area or of its authorities, or concerning the delimitation of its frontiers or boundaries. This map has been provided by the authors. 


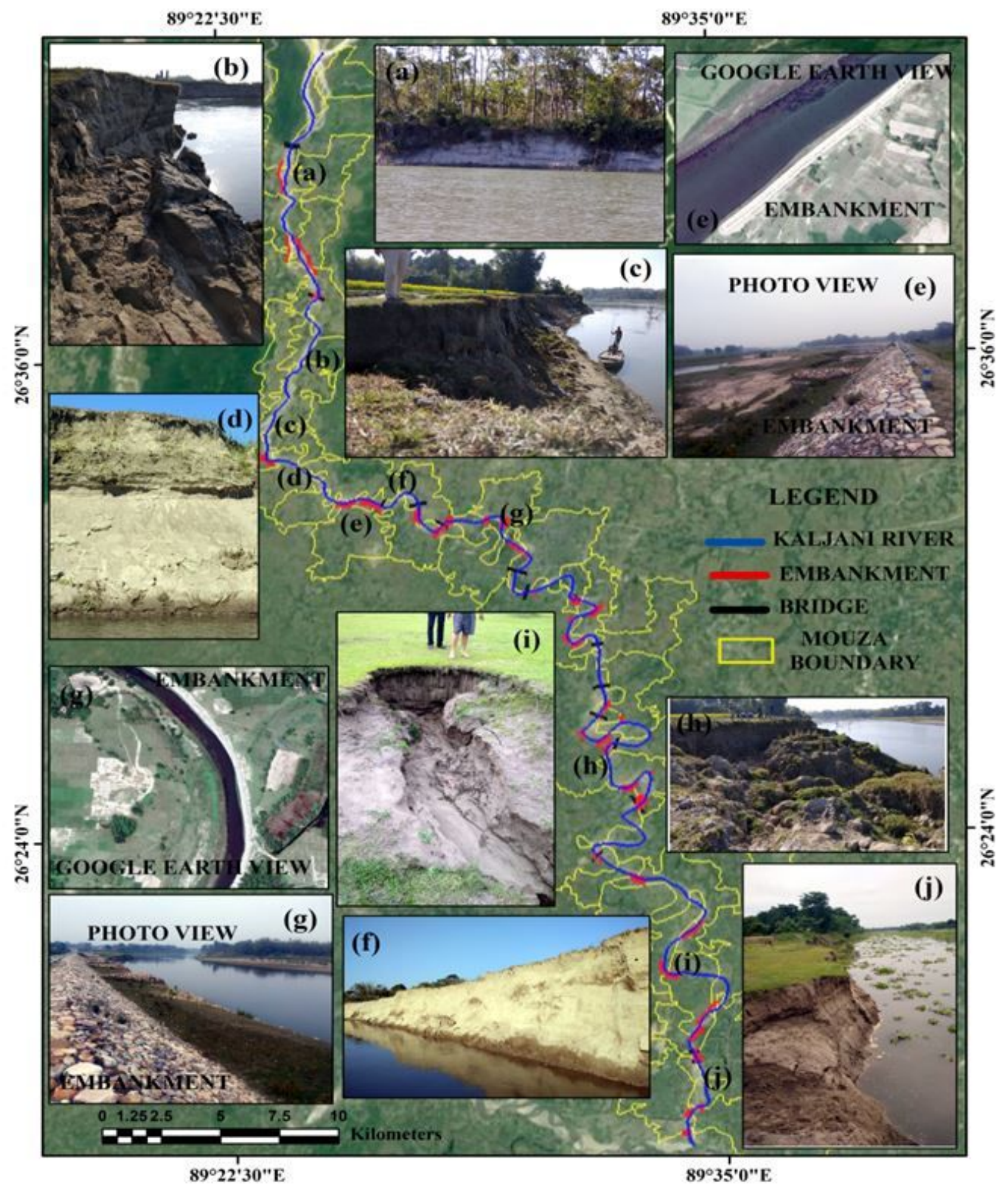

Figure 10

Bridges and embankment along the Kaljani River with field validation photos. 